\title{
Review \\ Innovating Strategies and Tailored Approaches in Neuro-Oncology
}

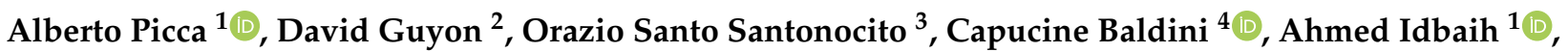 \\ Alexandre Carpentier ${ }^{5}$, Antonio Giuseppe Naccarato ${ }^{6,7}$ (D), Mario Caccese ${ }^{8}$, Giuseppe Lombardi ${ }^{8}$ (D) \\ and Anna Luisa Di Stefano ${ }^{3,9, *}$
}

check for updates

Citation: Picca, A.; Guyon, D.; Santonocito, O.S.; Baldini, C.; Idbaih, A.; Carpentier, A.; Naccarato, A.G.; Caccese, M.; Lombardi, G.; Di Stefano, A.L. Innovating Strategies and Tailored Approaches in Neuro-Oncology. Cancers 2022, 14 , 1124. https://doi.org/10.3390/ cancers14051124

Academic Editor: Hyunsuk Shim

Received: 30 December 2021

Accepted: 18 February 2022

Published: 22 February 2022

Publisher's Note: MDPI stays neutral with regard to jurisdictional claims in published maps and institutional affiliations.

Copyright: (C) 2022 by the authors. Licensee MDPI, Basel, Switzerland. This article is an open access article distributed under the terms and conditions of the Creative Commons Attribution (CC BY) license (https:/ / creativecommons.org/licenses/by/ $4.0 /)$.
1 Institut du Cerveau-Paris Brain Institute-ICM, Sorbonne Université, Inserm, CNRS, AP-HP, Hôpital Universitaire La Pitié Salpêtrière, DMU Neurosciences, 75013 Paris, France; picca.alberto@gmail.com (A.P.); ahmed.idbaih@aphp.fr (A.I.)

2 Department of Medical Oncology, Gustave Roussy University Hospital, 94800 Villejuif, France; david.guyon@gustaveroussy.fr

3 Division of Neurosurgery, Spedali Riuniti di Livorno-USL Toscana Nord-Ovest, 57124 Livorno, Italy; orazio.santonocito@uslnordovest.toscana.it

4 Drug Development Department (DITEP), Gustave Roussy University Hospital, 94800 Villejuif, France; capucine.baldini@gustaveroussy.fr

5 Service de Neurochirurgie, Hôpital Universitaire La Pitié Salpêtrière, 75013 Paris, France; alexandre.carpentier@aphp.fr

6 Department of Translational Research and New Technologies in Medicine and Surgery, Division of Pathology, University of Pisa, 56100 Pisa, Italy; giuseppe.naccarato@unipi.it

7 Anatomia Patologica 1, Department of Laboratory Medicine, Pisa University Hospital, 56126 Pisa, Italy

8 Department of Oncology, Oncology 1, Veneto Institute of Oncology IOV-IRCCS, 35128 Padua, Italy; mario.caccese@iov.veneto.it (M.C.); giuseppe.lombardi@iov.veneto.it (G.L.)

9 Department of Neurology, Foch Hospital, 92150 Suresnes, France

* Correspondence: annaluisa.distefano@uslnordovest.toscana.it

Simple Summary: Diffuse gliomas, including the most aggressive subtype glioblastoma, represent the most frequent primary central nervous system tumors. Despite intense chemoradiation protocols that represent the current standard of care, these cancers inevitably recur, and median overall survival does not exceed 18 months. New therapeutic options are compellingly needed for these tumors, particularly those lacking the favorable prognostic marker IDH mutation. Nonetheless, potentially druggable alterations are increasingly identified in distinct subsets of patients harboring gliomas. Targeted treatments, along with improved immunotherapeutic schedules, gene therapy, cell therapy, and physical strategies to improve drug delivery to the nervous system, are currently under extensive investigation. They bring hope for more effective therapies in these diseases with currently often a dismal outcome.

\begin{abstract}
Diffuse gliomas, the most frequent and aggressive primary central nervous system neoplasms, currently lack effective curative treatments, particularly for cases lacking the favorable prognostic marker IDH mutation. Nonetheless, advances in molecular biology allowed to identify several druggable alterations in a subset of IDH wild-type gliomas, such as NTRK and FGFR-TACC fusions, and $B R A F$ hotspot mutations. Multi-tyrosine kinase inhibitors, such as regorafenib, also showed efficacy in the setting of recurrent glioblastoma. IDH inhibitors are currently in the advanced phase of clinical evaluation for patients with IDH-mutant gliomas. Several immunotherapeutic approaches, such as tumor vaccines or checkpoint inhibitors, failed to improve patients' outcomes. Even so, they may be still beneficial in a subset of them. New methods, such as using pulsed ultrasound to disrupt the blood-brain barrier, gene therapy, and oncolytic virotherapy, are well tolerated and may be included in the therapeutic armamentarium soon.
\end{abstract}

Keywords: glioma; molecular markers; targeted therapies; immunotherapy; blood-brain barrier disruption 


\section{Introduction}

Gliomas represent approximately $26-40 \%$ of primary central nervous system (CNS) tumors, with estimated incidence rates of around 6 cases per 100,000 population/year (more than 22,600 newly diagnosed patients in the USA and 26,600 in the European Union every year) [1-3]. Glioblastoma (GBM), a grade 4 glioma [4], accounts for $60-70 \%$ of all malignant gliomas. The incidence of GBM increases with age and in males [1]. Glioblastoma has a dismal prognosis, with a median overall survival despite standard chemoradiation of 15 months, a 2-year survival rate of around $27 \%$ and a 5-year survival rate of only $9.8 \%$ [5].

Management of glioma patients is severely impacted by the absence of effective curative treatments, the limited number of therapeutic options, and the intrinsic clinical and biological heterogeneity even within the same histological subgroup. Recent advances in molecular biology allowed to refine the diagnostic and prognostic classification of gliomas and are paving the way for a personalized medicine targeting the main driver oncogenes at a patient level [6-11].

In this review, we will discuss the most relevant diagnostic molecular markers of diffuse gliomas and their role in improving the classification of CNS tumors, the main prognostic markers, and eventually the "theranostic" markers with their corresponding targeted therapies currently under study for glioma patients. We will also present innovative and promising strategies from recent clinical trials.

\section{The Integrated Histo-Molecular Classification and Personalized Management of Adult Diffuse Gliomas}

During recent decades, brain tumor classification has been primarily based on the histological concept that these neoplasms could be classified according to their microscopic similarities with the hypothesized cells of origin and the presumed level of differentiation [12]. Nonetheless, increased knowledge demonstrated that several acquired molecular alterations allow a better definition of the different biological entities and their clinical aggressiveness $[8,9,13,14]$.

Based on these advancements, since 2016, the World Health Organization (WHO) introduced the new paradigm of "integrated" histo-molecular classification [15]. In the WHO classification of adult diffuse gliomas, the status of two molecular alterations-namely, hotspot mutations in the genes coding for the isocitrate dehydrogenase [IDH] isoforms 1 and 2 , and the chromosomal codeletion $1 \mathrm{p} / 19 \mathrm{q}$, an unbalanced translocation resulting in the complete loss of the $1 \mathrm{p}$ and $19 \mathrm{q}$ chromosomal arms, is crucial in glioma taxonomy, irrespective of the histological grading. Accordingly, adult diffuse gliomas have been separated into three broad groups [4,15].

Astrocytomas are defined by the presence of an $I D H$ mutation without $1 \mathrm{p} / 19 \mathrm{q}$ codeletion. This group includes less aggressive grade 2 and 3 gliomas, but also gliomas with histological grade 4 features (i.e., necrosis and/or microvascular proliferation), corresponding to the malignant progression of a former lower grade glioma and previously indicated as "secondary GBMs". For them, the new definition of "astrocytoma, grade 4 " has been established $[4,16]$. The presence of the homozygous deletion of the CDKN2A gene defines a group of patients with a worse prognosis [14], and it allows alone the classification of a tumor as "astrocytoma, grade 4" regardless of the histological features [4].

Oligodendrogliomas are specifically defined by the presence of the $1 p / 19 q$ codeletion, that invariably associate with an IDH mutation. They constitute a subgroup of grade 2-3 gliomas with the best prognosis and a pronounced chemo- and radio-sensitivity.

$I D H$ wild-type gliomas are the most aggressive entity regardless of histological grading [17]. The presence of at least one of the following: (i) EGFR gene amplification; (ii) chromosome 7 gain plus chromosome 10 loss; (iii) hotspot TERT promoter mutation, considered molecular markers of GBM, is sufficient to define an IDH wild-type diffuse glioma as GBM, independently of its histological appearance $[4,18]$, although this remains partly disputed [17]. 
The identification of these three histo-molecular entities enables to personalize the treatment strategy (Table 1) [19,20].

Table 1. Trials of reference for conventional anti-tumor treatments in glioma patients. ECOG = Eastern Cooperative Oncology Group Performance Status Scale, Gy = Gray, KPS = Karnofsky Performance Status, NCT ID = National Clinical Trials identifier, PCV = procarbazine, lomustine, and vincristine polychemotherapy, $\mathrm{RT}=$ radiotherapy, $\mathrm{TMZ}=$ temozolomide, yo = year old.

\begin{tabular}{|c|c|c|c|c|}
\hline $\begin{array}{l}\text { Histo-Molecular } \\
\text { Subgroup }\end{array}$ & Clinical Features & $\begin{array}{l}\text { Therapeutical } \\
\text { Intervention }\end{array}$ & NCT ID & Reference \\
\hline \multirow{5}{*}{ Glioblastoma } & $\begin{array}{c}\mathrm{KPS} \geq 70 \text { and age } \leq \\
65 \text { yo }\end{array}$ & $\begin{array}{c}\text { Concomitant RT (60 Gy) } \\
+ \text { TMZ followed by } \\
\text { adjuvant TMZ }\end{array}$ & NCT00006353 & $\begin{array}{l}\text { Stupp et al. NEJM } \\
2005[21]\end{array}$ \\
\hline & Age $>65$ yo & $\begin{array}{c}\text { Short-course concomitant } \\
\text { RT ( } 40 \text { Gy) + TMZ } \\
\text { followed by adjuvant TMZ }\end{array}$ & NCT00482677 & $\begin{array}{l}\text { Perry et al. NEJM } \\
2017 \text { [22] }\end{array}$ \\
\hline & Age $\geq 70 ; \mathrm{KPS} \leq 70$ & TMZ & NCT01242566 & $\begin{array}{l}\text { Pérez-Larraya et al. } \\
\text { JCO } 2011 \text { [23] }\end{array}$ \\
\hline & $\begin{array}{l}\text { KPS } \geq 60 \text { and } \geq 65 \text { yo; } \\
\text { pMGMT methylated }\end{array}$ & TMZ & NCT01502241 & $\begin{array}{l}\text { Wick et al. Lancet } \\
\text { Oncol } 2012 \text { [24] }\end{array}$ \\
\hline & $\begin{array}{c}\text { KPS } \geq 60 \text { and } \geq 65 \text { yo; } \\
\text { pMGMT non-methylated }\end{array}$ & RT (60 Gy) & NCT01502241 & $\begin{array}{l}\text { Wick et al. Lancet } \\
\text { Oncol } 2012 \text { [24] }\end{array}$ \\
\hline \multirow{2}{*}{$\begin{array}{c}\text { Grade } 3 \\
\text { oligodendroglioma, } \\
\text { IDH mutated and } \\
\text { 1p19q co-deleted }\end{array}$} & $\mathrm{KPS} \geq 60$ & $\begin{array}{l}\text { PCV followed by RT } \\
(59.4 \mathrm{~Gy})\end{array}$ & NCT00002569 & $\begin{array}{c}\text { Cairncross et al. JCO } \\
2013 \text { [25] }\end{array}$ \\
\hline & $\mathrm{ECOG} \leq 2$ & $\begin{array}{c}\text { RT (59.4 Gy) followed } \\
\text { by PCV }\end{array}$ & NCT00002840 & $\begin{array}{l}\text { Van den Bent et al. } \\
\text { JCO } 2013 \text { [26] }\end{array}$ \\
\hline \multirow{2}{*}{$\begin{array}{l}\text { Grade } 3 \text { astrocytoma, } \\
\text { IDH mutated }\end{array}$} & $\mathrm{KPS} \geq 60$ & $\begin{array}{l}\text { PCV followed by RT } \\
\text { (59.4 Gy) }\end{array}$ & NCT00002569 & $\begin{array}{c}\text { Cairncross et al. JCO } \\
2013 \text { [25] }\end{array}$ \\
\hline & $\mathrm{ECOG} \leq 2$ & $\begin{array}{l}\text { RT (59.4 Gy) followed by } \\
\text { adjuvant TMZ }\end{array}$ & NCT00626990 & $\begin{array}{l}\text { Van den Bent et al. } \\
\text { The Lancet } 2017 \text { [27] }\end{array}$ \\
\hline $\begin{array}{l}\text { Grade } 2 \text { astrocytoma, } \\
\text { IDH mutated }\end{array}$ & $\begin{array}{l}\mathrm{KPS} \geq 60 ; \text { subtotal } \\
\text { resection or age } \geq 40 \text { yo }\end{array}$ & $\begin{array}{c}\text { RT (54 Gy) followed } \\
\text { by PCV }\end{array}$ & NCT00003375 & $\begin{array}{c}\text { Buckner et al. NEJM } \\
2016[28]\end{array}$ \\
\hline
\end{tabular}

Grade 4 gliomas (both IDH mutated astrocytomas and IDH wildtype GBMs): patients with a good Karnofsky performance status (KPS > 70) and age less than 65 years are treated with six weeks concomitant chemoradiation followed by adjuvant temozolomide (the socalled "Stupp protocol") [5,21]. For patients older than 65 years and/or a KPS $<70$, 3-week hypofractionated radiotherapy is recommended [22], with or without temozolomide. The O6-methylguanine-DNA-methyltransferase (MGMT) promoter methylation status may be helpful in clinical decision making of adding alkylating temozolomide, although this remains debated (see above).

Grade 3 oligodendroglioma (IDH mutated and 1p/19q co-deleted) patients receive radiotherapy plus the procarbazine, $\mathrm{CCNU}$, and vincristine $(\mathrm{PCV})$ polychemotherapy $[25,26]$.

Grade 3 astrocytomas (IDH mutated and 1p/19q non co-deleted) are treated with radiotherapy plus adjuvant temozolomide [27,29] or adjuvant PCV [25].

Grade 2 gliomas, IDH mutated (with or without the $1 \mathrm{p} / 19 \mathrm{q}$ codeletion) considered at high risk because of the age at diagnosis (more than 40 years) or the presence of a residual tumor after surgery: the benefit of the radiotherapy plus the PCV chemotherapy has been reported in a phase 3 randomized clinical trial [28].

Grade 2 and 3 gliomas, IDH wild-type: they are currently considered aggressive tumors and patients are often treated with the Stupp protocol [17]. 


\section{The Clinical Utility of the MGMT Gene Promoter Methylation Status}

MGMT gene promoter ( $\mathrm{pMGMT}$ ) methylation is a well-recognized predictive marker of sensitivity to alkylating agents in IDH wildtype gliomas [30-33]. MGMT gene codes for a DNA repair enzyme that removes mutagenic alkyls from the O6 position of guanine. The promoter hypermethylation results in reduced gene expression (epigenetic silencing). Patients with pMGMT hypermethylation have an increased progression-free survival and a 21.7 months overall survival after standard chemoradiation, significantly longer than those without gene promoter hypermethylation [30].

Nonetheless, the clinical benefit at the 5-years timepoint of the concomitant treatment with radiochemotherapy compared to radiotherapy alone seems to be also present in a part of the pMGMT non-methylated patient cohort [5]. Consequently, the pMGMT methylation status should not be considered as a formal discriminant while choosing the therapeutic strategy to be adopted in the first line setting of a young, otherwise healthy patient with a newly diagnosed GBM.

On the other hand, in elderly or frail subjects, who could be ineligible to radiotherapy, the presence of $\mathrm{p} M G M T$ hypermethylation and its predictive value for response to alkylating agents could motivate the initiation of treatment with chemotherapy alone rather than upfront palliative care, due to the reasonable hope of functional and neurological improvement $[23,24,34]$. Conversely, in elderly patients with unmethylated $\mathrm{pMGMT}$, the benefit/risk balance favors radiotherapy alone [19].

Given its major predictive value, pMGMT methylation status is now considered crucial in the design of clinical trials of patients with newly diagnosed GBM $[35,36]$.

\section{Theranostic Markers and Targeted Treatments}

In the recurring setting, therapeutic options are limited. Nitrosoureas [37] and/or the antiangiogenic agent bevacizumab [38] are usually discussed as second line treatments $[19,20]$. Concerning the potential targeted therapies, we will discuss in the following paragraphs the most promising actionable pathways in patients affected by gliomas.

\section{Tyrosine Kinase Inhibition}

\subsection{Multi-Kinase Inhibitors}

Tyrosine kinase receptors are transmembrane proteins involved in several cellular processes, including cell differentiation, regulation of proliferation, survival, metabolism, cell cycle control and cell migration. Because of their well-recognized oncogenic potential, they have been largely studied in oncology and several targeted compounds capable of blocking their activity have been developed. Furthermore, in neuro-oncology, different lines of research have explored the ability of different tyrosine kinase inhibitors (TKIs) to improve patient outcome, especially in the recurrent setting. Encouraging data derive from the use of regorafenib (Figure 1A-D), an oral multi-kinase inhibitor targeting VEGFR1-3, PDGFR, TIE2, FGFR, RAF-1, KIT, RET, and BRAF. The drug has been evaluated for the treatment of recurrent GBM patients in the randomized phase II trial REGOMA (Table 2) [39]. In this study, the use of regorafenib resulted in a significant benefit in terms of 6 months progression free and overall survival, as well as in terms of disease control rate compared to the standard of care lomustine, with a manageable toxicity profile [39]. Subsequent studies evaluated the presence of any predictors of response to regorafenib in patients with recurrent GBM. The activation of the AMPK pathway appeared associated with a clinical benefit from treatment with regorafenib in the same patient population [40], while the expression of 2 gene transcripts (HIF1A, CDKN1A) and 3 miRNAs (miR-3607-3p, miR-301a-3p, miR-93-5p) could help identify a subgroup of GBM patients exhibiting a striking survival advantage when treated with regorafenib [41]. Based on these data, the NCCN guidelines have included regorafenib as the preferred regimen in cases of recurrent GBM. The combination of regorafenib and the anti PD-1 immune-checkpoint inhibitor (ICI) nivolumab is currently evaluated in the ongoing phase II multi-indication study (NCT04704154, Table 2), but results are not yet available. 


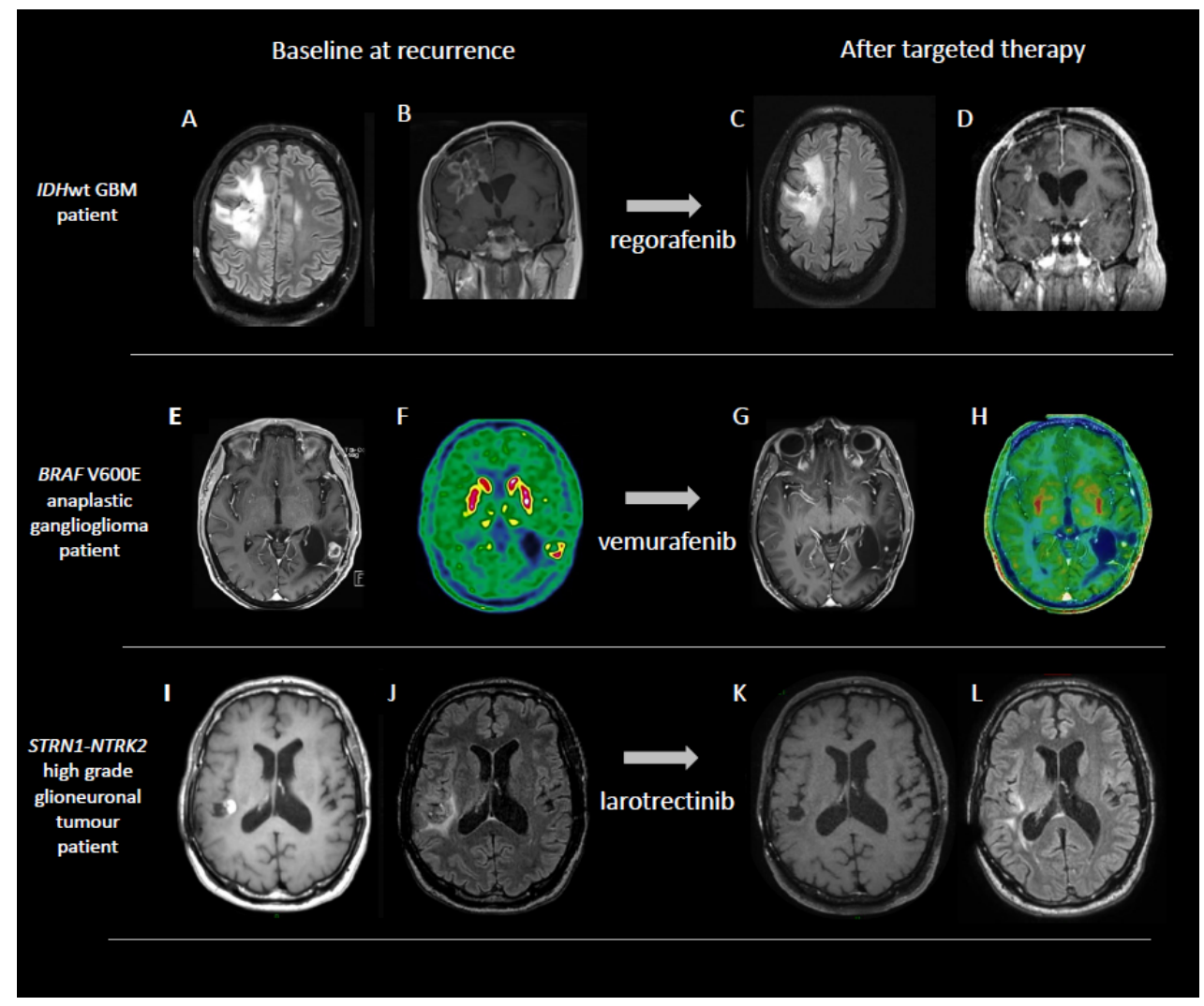

Figure 1. Examples of objective responses to tyrosine kinase inhibition in patients with primary brain tumors. Panels (A-D): tumor response after two cycles of regorafenib in a 49-year-old patient with recurrent $I D H$ wild-type GBM. Panels $(\mathbf{E}-\mathbf{H})$ : tumor response after three cycles of vemurafenib in a 38-year-old patient affected by recurrent $B R A F$ mutant anaplastic ganglioglioma (case already reported in ref. [42]). Panels (I-L): a 53-year-old patient with STRN1-NTRK2 fusion positive high grade glioneuronal tumor treated with larotrectinib and experiencing a complete tumor response (case already reported in ref. [43]).

Table 2. Innovating strategies and targeted therapies: completed and recruiting trials. CNS = central nervous system, ECOG = Eastern Cooperative Oncology Group Performance Status Scale, KPS = Karnofsky Performance Status, LIPU: low intensity pulsed ultrasound, NCT ID = National Clinical Trials identifier, RT = radiotherapy, TMZ = temozolomide, yo = year old.

\begin{tabular}{ccccc}
\hline $\begin{array}{c}\text { Histo-Molecular Subgroup } \\
\text { and Disease Stage }\end{array}$ & Clinical Features & $\begin{array}{c}\text { Therapeutical } \\
\text { Intervention }\end{array}$ & NCT ID, Status & Reference \\
\hline Recurrent glioblastoma & ECOG 0-1 & Regorafenib & $\begin{array}{c}\text { NCT02926222, } \\
\text { completed }\end{array}$ & $\begin{array}{c}\text { Lombardi et al. Lancet } \\
\text { Oncology 2019 [39] }\end{array}$ \\
\hline $\begin{array}{c}\text { Recurrent glioblastoma and } \\
\text { grade 3 astrocytoma }\end{array}$ & ECOG 0-1 & $\begin{array}{c}\text { Regorafenib plus } \\
\text { nivolumab }\end{array}$ & $\begin{array}{c}\text { NCT04704154, } \\
\text { recruiting }\end{array}$ \\
\hline $\begin{array}{c}\text { Newly diagnosed and } \\
\text { recurrent glioblastoma }\end{array}$ & KPS $\geq 60$ & $\begin{array}{c}\text { TMZ, lomustine, } \\
\text { paxalisib, or VAL-083 } \\
\text { (Bayesian response } \\
\text { adaptive } \\
\text { randomization) }\end{array}$ & $\begin{array}{c}\text { NCT03970447, } \\
\text { recruiting }\end{array}$ \\
\hline $\begin{array}{c}\text { Recurrent } B R A F \\
\text { V600E-mutant glioma }\end{array}$ & ECOG $\leq 2$ & Vemurafenib & NCT01524978, \\
completed
\end{tabular}


Table 2. Cont.

\begin{tabular}{|c|c|c|c|c|}
\hline $\begin{array}{l}\text { Histo-Molecular Subgroup } \\
\text { and Disease Stage }\end{array}$ & Clinical Features & $\begin{array}{l}\text { Therapeutical } \\
\text { Intervention }\end{array}$ & NCT ID, Status & Reference \\
\hline $\begin{array}{c}\text { Recurrent } B R A F \\
\text { V600E-mutant glioma }\end{array}$ & $\mathrm{ECOG} \leq 2$ & $\begin{array}{l}\text { Dabrafenib and } \\
\text { trametinib }\end{array}$ & $\begin{array}{l}\text { NCT02034110, } \\
\text { completed }\end{array}$ & $\begin{array}{l}\text { Wen et al. Lancet } \\
\text { Oncol } 2022 \text { [45] }\end{array}$ \\
\hline $\begin{array}{c}\text { FGFR3-TACC3+ recurrent } \\
\text { glioblastoma }\end{array}$ & $\mathrm{ECOG} \leq 2$ & AZD4547 & $\begin{array}{l}\text { NCT02824133, } \\
\text { completed }\end{array}$ & \\
\hline $\begin{array}{l}\text { FGFR3-TACC3+ or FGFR1 } \\
\text { mutant recurrent gliomas }\end{array}$ & ECOG 0-1 & TAS120 & $\begin{array}{l}\text { NCT02052778, active } \\
\text { (not recruiting) }\end{array}$ & \\
\hline $\begin{array}{l}\text { Recurrent solid tumors in } \\
\text { CNS harboring } \\
\text { NTRK Fusions }\end{array}$ & $\mathrm{ECOG} \leq 3$ & Larotrectinib & $\begin{array}{l}\text { NCT02576431, } \\
\text { recruiting }\end{array}$ & \\
\hline $\begin{array}{c}\text { IDH1 mutated } \\
\text { advanced glioma }\end{array}$ & ECOG 0-1 & Ivosidenib & $\begin{array}{l}\text { NCT02073994, active } \\
\text { (not recruiting) }\end{array}$ & $\begin{array}{l}\text { Mellinghoff et al. JCO } \\
2020 \text { [46] }\end{array}$ \\
\hline $\begin{array}{l}\text { IDH1 or IDH2 mutated } \\
\text { recurrent or } \\
\text { progressive glioma }\end{array}$ & $\mathrm{ECOG} \leq 2$ & Vorasidenib & $\begin{array}{l}\text { NCT02481154, active } \\
\text { (not recruiting) }\end{array}$ & $\begin{array}{l}\text { Mellinghoff et al. Clin } \\
\text { Cancer Res. 2021 [47] }\end{array}$ \\
\hline $\begin{array}{l}\text { Residual or recurrent IDH } \\
\text { mutated grade } 2 \text { glioma }\end{array}$ & $\mathrm{KPS} \geq 80$ & Vorasidenib & $\begin{array}{l}\text { NCT04164901, } \\
\text { recruiting }\end{array}$ & \\
\hline $\begin{array}{c}\text { Contrast enhancing IDH1 } \\
\text { mutated glioma }\end{array}$ & ECOG 0-1 & $\begin{array}{l}\text { Ivosidenib plus } \\
\text { Nivolumab }\end{array}$ & $\begin{array}{l}\text { NCT04056910, } \\
\text { recruiting }\end{array}$ & \\
\hline $\begin{array}{l}\text { Recurrent } I D H \text { mutated } \\
\text { grade } 2 \text { and } 3 \text { glioma }\end{array}$ & KPS $>50$ & Azacytidine & $\begin{array}{l}\text { NCT03666559, } \\
\text { recruiting }\end{array}$ & \\
\hline & & Immunotherapy & & \\
\hline Recurrent glioblastoma & $\mathrm{KPS} \geq 60$ & $\begin{array}{l}\text { Relatlimab with or } \\
\text { without nivolumab }\end{array}$ & $\begin{array}{l}\text { NCT02658981, } \\
\text { recruiting }\end{array}$ & \\
\hline Recurrent glioblastoma & $\mathrm{KPS} \geq 60$ & $\begin{array}{l}\text { INCMGA00012 and } \\
\text { Epacadostat in } \\
\text { Combination with RT } \\
\text { and Bevacizumab }\end{array}$ & $\begin{array}{l}\text { NCT03532295, } \\
\text { recruiting }\end{array}$ & \\
\hline $\begin{array}{l}\text { Newly diagnosed } \\
\text { glioblastoma }\end{array}$ & $\mathrm{KPS} \geq 70$ & $\begin{array}{l}\text { Nivolumab, } \\
\text { BMS-986205, and RT } \\
\text { with or without } \\
\text { Temozolomide }\end{array}$ & $\begin{array}{l}\text { NCT04047706, } \\
\text { recruiting }\end{array}$ & \\
\hline $\begin{array}{l}\text { Recurrent glioblastoma with } \\
\text { tumor mutational } \\
\text { burden } \geq 10\end{array}$ & $\mathrm{ECOG} \leq 2$ & $\begin{array}{l}\text { Ipilimumab and } \\
\text { Nivolumab }\end{array}$ & $\begin{array}{l}\text { NCT04145115, } \\
\text { recruiting }\end{array}$ & \\
\hline $\begin{array}{l}\text { Recurrent glioblastoma with } \\
\text { MMP2 expression }\end{array}$ & $\mathrm{KPS} \geq 60$ & $\begin{array}{l}\text { Chlorotoxin-CAR } \\
\text { T-lymphocytes }\end{array}$ & $\begin{array}{l}\text { NCT04214392, } \\
\text { recruiting }\end{array}$ & \\
\hline \multicolumn{5}{|c|}{ Gene therapy and virotherapy } \\
\hline Recurrent glioblastoma & $\begin{array}{c}\text { Age } \leq 75 \text { yo and } \\
\text { KPS } \geq 70\end{array}$ & $\begin{array}{l}\text { Ad-RTS-hIL-12 plus } \\
\text { veledimex and } \\
\text { cemiplimab }\end{array}$ & $\begin{array}{l}\text { NCT04006119, } \\
\text { completed }\end{array}$ & \\
\hline $\begin{array}{l}\text { Surgically accessible } \\
\text { recurrent glioblastoma }\end{array}$ & $\mathrm{KPS} \geq 70$ & $\begin{array}{l}\text { VB-111 neoadjuvant } \\
\text { and adjuvant versus } \\
\text { adjuvant only versus } \\
\text { bevacizumab }\end{array}$ & NCT04406272, ongoing & \\
\hline Recurrent glioblastoma & $\mathrm{KPS} \geq 70$ & $\begin{array}{l}\text { DNX-2401 plus } \\
\text { pembrolizumab }\end{array}$ & $\begin{array}{l}\text { NCT02798406, } \\
\text { completed }\end{array}$ & \\
\hline $\begin{array}{c}\text { Newly diagnosed grade } 3 \\
\text { and } 4 \text { glioma }\end{array}$ & $\mathrm{KPS} \geq 70$ & $\begin{array}{l}\text { Ad-TK + Ad-Flt3L } \\
\text { combination therapy }\end{array}$ & $\begin{array}{l}\text { NCT01811992, } \\
\text { completed }\end{array}$ & \\
\hline
\end{tabular}


Table 2. Cont.

\begin{tabular}{ccccc}
\hline $\begin{array}{c}\text { Histo-Molecular Subgroup } \\
\text { and Disease Stage }\end{array}$ & Clinical Features & $\begin{array}{c}\text { Therapeutical } \\
\text { Intervention }\end{array}$ & NCT ID, Status & Reference \\
\hline Becurrent glioblastoma & KPS $\geq 70$ & LIPU and carboplatine & $\begin{array}{c}\text { NCT02253212, } \\
\text { completed }\end{array}$ & $\begin{array}{c}\text { Idbaih et al. Clin } \\
\text { Cancer Res. 2019 [48] }\end{array}$ \\
\hline Recurrent glioblastoma & KPS $\geq 70$ & LIPU and carboplatine & $\begin{array}{c}\text { NCT03744026, } \\
\text { completed }\end{array}$ \\
\hline $\begin{array}{l}\text { Newly diagnosed IDH } \\
\text { wildtype glioblastoma }\end{array}$ & $\begin{array}{c}\text { Age } \leq 70 \text { yo and } \\
\text { KPS } \geq 70\end{array}$ & $\begin{array}{c}\text { LIPU plus concurrent } \\
\text { chemoradiation and } \\
\text { adjuvant } \\
\text { temozolomide }\end{array}$ & $\begin{array}{c}\text { NCT04614493, } \\
\text { recruiting }\end{array}$ \\
\hline
\end{tabular}

Another response adaptive randomization platform phase II/III trial is currently active, with the aim of evaluating multiple treatment regimens for newly diagnosed and recurrent GBM patients (GBM AGILE, NCT03970447). A Bayesian response adaptive randomization allocates the enrolled patients in different treatment arms including regorafenib, temozolomide, lomustine, the PI3K/AKT/mTOR inhibitor paxalisib, and the alkylating agent VAL-083 (Table 2).

\subsection{MAP-Kinase Pathway Inhibition}

The proto-oncogene BRAF codes for the B-Raf serine/threonine kinase, part of the Raf kinase protein family involved in the activation of the oncogenic Mitogen-Activated Protein Kinase (MAPK) pathway. The BRAF V600E mutation is a recurrent alteration in xanthoastrocytomas, glioneuronal tumors, pilocytic astrocytomas, and, less frequently, diffuse astrocytomas $[49,50]$. The total frequency of $B R A F$ mutations in gliomas remains below $6 \%$.

This alteration is involved in tumoral proliferation; the therapeutic opportunity stems from the actionable nature of the BRAF V600E mutation, initially recognized in nonneurological tumors, notably metastatic melanoma [51]. BRAF V600E inhibitors (BRAFi) reduce MAPK phosphorylation thereby affecting apoptosis and inhibiting the progression in the cell cycle. The association with MAPK/ERK Kinase (MEK) inhibitors (MEKi), acting downstream in the same pathway, increase the signal blockade and improve clinical safety $[52,53]$.

Clinical responses may vary from prolonged responses with a remarkable clinical benefit to primary resistance to the targeted therapy. The response rate in BRAF V600E-mutant gliomas exceeds $30 \%$, with associated clinical benefit and prolonged tumor control [42] (Figure 1E-H). Rechallenging with BRAFi +/- MEKi at recurrence in patients initially responding to these targeted therapies may also be effective, as recently reported [54].

It should be noted that targeted approaches with BRAF inhibitors could provide fruitful options in other BRAF V600E mutated brain tumors such as the aggressive or rapidly progressive papillary craniopharyngioma [55] and rhabdoid meningioma meningioma [50]. Although the estimated prevalence of BRAF V600 mutations in GBM is low (about 2\%) [49,50], given its significant therapeutic implication, routine screening for BRAF mutations should also be strongly encouraged in this setting.

\subsection{Inhibition of FGFR3-TACC3 Gene Fusions and Activating Mutations of FGFR1 Gene}

The disruption of the Fibroblast Growth Factor Receptors (FGFR) pathway is a recurrent alteration affecting approximately $7 \%$ of solid cancers. Involved mechanisms may be ligand-dependent or independent, such as gene amplifications, activating mutations, and chromosomal translocations, which all lead to aberrant activation of the tyrosine kinase domain [56]. Several small molecule inhibitors, ligand traps, and monoclonal antibodies are currently being tested in various cancers [56]. 
Two rare FGFR alterations have been consistently reported in gliomas: fusions involving the families of genes FGFR and TACC (mostly FGFR3-TACC3) [57,58], and hotspot mutations N546 and K656 in FGFR1 gene [59], showing a major therapeutic convergence from the possibility of treating patients with targeted anti-FGFR compounds. The inhibition of FGFR kinase resulted in clinical benefit in patients harboring the oncogenic fusion FGFR3-TACC3 [60] (Figure 2), and different FGFR inhibitors are currently on trial (AZD4547, NCT02824133; TAS120, NCT02052778; erdafitinib, NCT04083976) (Table 2).

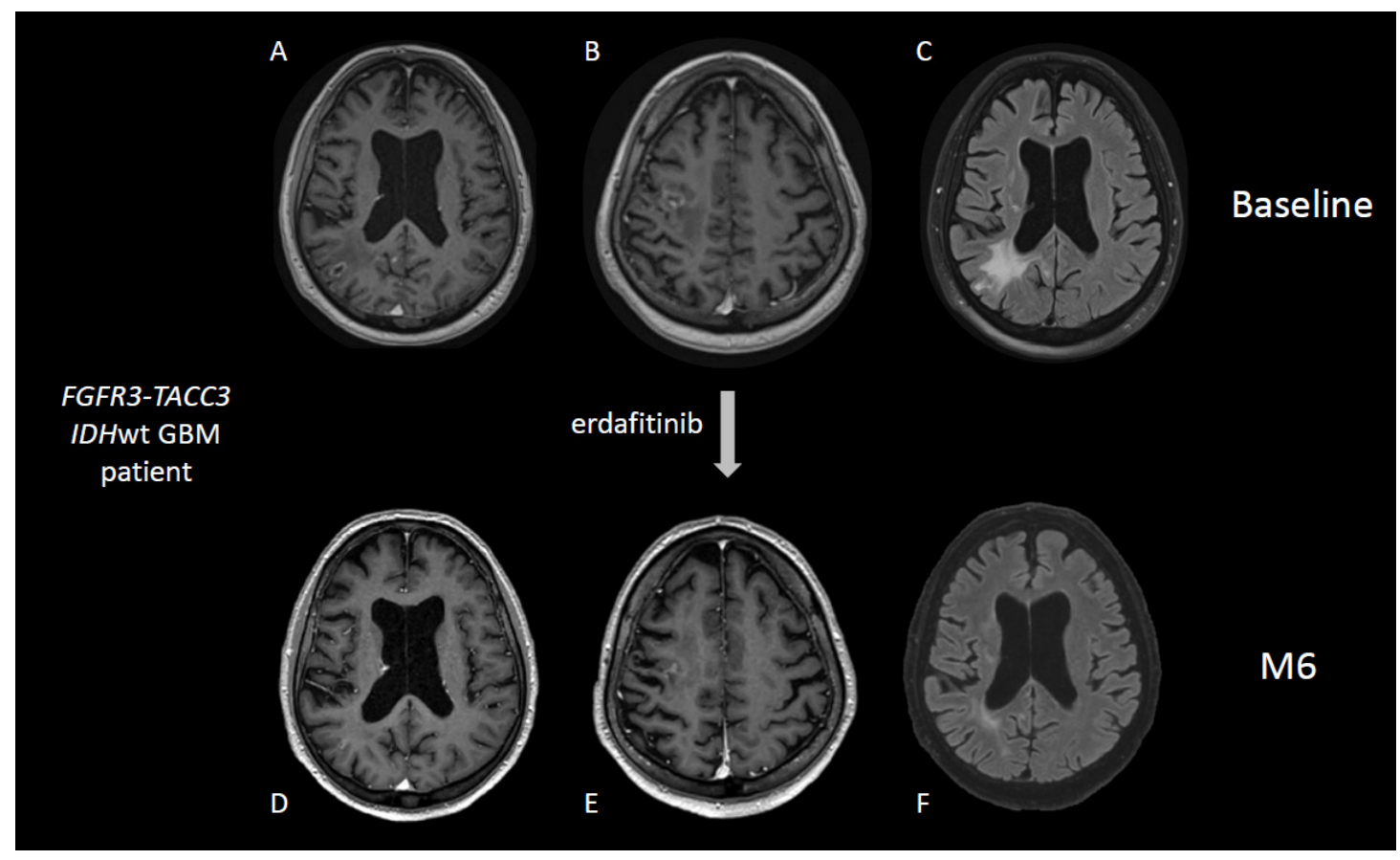

Figure 2. 57-year-old patient with an IDH wild-type, FGFR3-TACC3 fusion positive GBM treated at recurrence with the FGFR inhibitor erdafitinib. Brain MRI imaging at baseline (Panels A-C) and after 6 months of therapy (Panels D-F).

Hotspots FGFR1 N546 and K656 mutations are recurrent in adult midline gliomas (affecting the thalamus, diencephalon, brainstem, and spine) [61,62], with a reported incidence of up to $18 \%$ regardless of grading, location, histological type, and other molecular alterations [59]. Based on the activating effect of these mutations [61], patients harboring these alterations have been treated with FGFR inhibitors [63] (TAS120, NCT02052778) (Table 2), results are currently awaited.

Screening for FGFR3-TACC3 fusions and FGFR1 activating mutations should be performed in all patients with newly diagnosed IDH wild-type gliomas and all midline gliomas, respectively, as these patients are potentially eligible for clinical trials of targeted therapies at recurrence (Table 2).

\subsection{NTRK Pathway Inhibition}

Three different genes (NTRK1, NTRK2, and NTRK3) encode for the NeurotrophicTropomyosin Receptor tyrosine Kinases (TRK). Fusions involving the NTRK genes are actionable oncogenic drivers involved in several cancers [64]. Rapid and sustained responses have been obtained in 60 to $80 \%$ of cases, including advanced or metastatic disease, with TRK inhibitors. An efficacy superior to 50\% has been observed in paediatric gliomas [65].

The incidence of NTRK gene fusions in adult glioma patients remains rare, estimated at $2 \%$ [66]. The use of TRK small molecule inhibitors (first generation: larotrectinib and entrectinib, second generation: selitrectinib and repotrectinib) has shown to induce dramatic, durable responses in patients with primary or metastatic brain lesions $[43,67,68]$ (Figure 1I-L), demonstrating blood-brain barrier crossing and intracranial activity. Phase 
I and II basket trials are currently ongoing in solid tumors including brain tumors [66] (Table 2).

Nonetheless, resistance phenomena may be observed. A frequent escape mechanism is the occurrence of a new mutation in the receptor tyrosine kinase. Resistance by activation of the MAPK pathway may also occur; hence the interest, as in the case of BRAF mutations, of associating an anti-MEK treatment [69].

\subsection{Other Tyrosine Kinase Inhibitors}

EGFR gene alterations are present in approximately $25 \%$ of gliomas [7]. Several EGFR TKI have been evaluated as possible treatments in patients diagnosed with glioma. Erlotinib and gefitinib, first-generation EGFR inhibitors, despite having shown interesting data in the preclinical setting [70], did not then lead to an improvement in the outcome and response parameters in the treatment of patients with GBM, both as first-line treatment and at relapse [71-75]. Second-generation inhibitors (afatinib and dacomitinib), again, did not result in a clinical benefit for GBM patients, showing limited activity both in combination with temozolomide and as single-agents [76,77].

Other small molecules, VEGFR TKI, have been evaluated as possible treatments in glioma patients: cediranib [78], sorafenib [79,80], sunitinib [81], pazopanib [82], and cabozantinib [83] were tested without however significant results in terms of responses and outcomes [84].

A further target of interest is PDGFR, another tyrosine kinase receptor often overexpressed in high-grade gliomas [85]. Imatinib, a TKI capable of blocking PDGFR, although it has shown evident efficacy in various types of cancer, has not shown significant activity in high-grade gliomas, neither alone nor in association with hydroxyurea [86,87]. Tandutinib, an oral PDGFR $\beta$ kinase inhibitor that demonstrated activity in patients with relapsed and refractory acute myelocytic leukemia, was also tested in patients with relapsed high-grade glioma in a phase II study in combination with bevacizumab. It showed an efficacy comparable to that of bevacizumab alone, with neuro-muscular junction pathologies as distinctive toxicity [88].

\section{Additional Approaches Targeting EGFR Alterations}

The Epidermal Growth Factor Receptor (EGFR) is part of the broad group of receptor tyrosine kinases; according to The Cancer Genome Atlas (TCGA) data, alterations of EGFR gene are present in around $25 \%$ of gliomas: $54 \%$ of GBMs and $9 \%$ of lower grade gliomas [7]. Unfortunately, several small molecule TKI approved for systemic cancers have shown disappointing results in the setting of high-grade glioma patients (see above).

Regarding EGFR gene amplification, the phase II trial testing ABT-414 (also known as depatuxizumab mafodotin), an anti-EGFR monoclonal antibody conjugated to a potent antimitotic agent (monomethyl auristatin F), in patients with a recurring GBM with EGFR amplification, observed a response in $39 \%$ of patients [26]. Unfortunately, the phase III trial including patients with newly diagnosed GBM (INTELLANCE1, NCT02573324) [89] has been interrupted for futility.

The EGFR truncated transcript variant III, or EGFRvIII, is a molecular alteration that results in constitutive pathway activation and is found in approximately $20 \%$ of GBMs [7]. Rindopepimut is a peptide vaccine directed against EGFRvIII. The compound has been tested in a phase III randomized clinical trial (ACT IV, NCT01480479), that has been regrettably interrupted because of futility [90]. The main hypotheses to explain this failure have been, on the one hand, the heterogeneous expression of EGFRvIII, that, by selection pressure, results in the proliferation of tumor cells without the targeted alteration, and, on the other hand, the instability of the EGFRvIII antigen during the course of the disease [91]. Nonetheless, the concomitant approach of peptide vaccination combined with immunostimulating compounds (namely, ICIs, see below) remains a promising field requiring further clinical research. 


\section{IDH Inhibition}

IDH gene mutation is an early event in gliomagenesis [92,93] and plays a crucial role in initiating and sustaining astrocytomas and oligodendrogliomas growth. IDH mutated gliomas represent a distinct molecular entity among gliomas, in terms of evolution, prognosis, and response to treatments [94,95]. IDH hotspot mutations result in a neomorphic IDH enzymatic activity with the consequent accumulation of the oncometabolite D-2hydroxyglutarate (D2HG) [96]. D2HG inhibits several $\alpha$-ketoglutarate depending enzymes, including the TET family of DNA demethylases [97]. This results in a specific epigenetic signature, corresponding to a diffuse genome hypermethylation (glioma CpG island methylator phenotype, G-CIMP) [98] and consequent cellular dedifferentiation sustaining tumor growth. Several approaches are currently in study to target the enzymatic and epigenetic peculiarities of IDH mutated gliomas [94,95].

Several small molecule inhibitors of IDH have been developed [95] (Table 2). Ivosidenib (AG-120) is an oral inhibitor of the IDH1 mutated enzyme, while enasidenib (AG-221) inhibits mutated IDH2; both are approved for the treatment of acute myeloid leukaemia (AML). A phase I basket trial exploring the feasibility of ivosidenib treatment in IDH mutated solid tumors (NCT02073994) included 66 patients with advanced gliomas. The drug was well tolerated, and showed signs of activity, particularly in non-enhancing diffuse gliomas $(66.7 \%$ of them showed a reduction of tumor volume, with a median reduction of 6-months tumor volume growth rate from $26 \%$ pretreatment to $9 \%$ under treatment) [46].

Vorasidenib (AG-881) is a dual inhibitor of both mutant IDH1 and IDH2. Phase I trial NCT02481154 included 52 patients with IDH mutated gliomas recurring after or not responders to standard treatment. Again, non-enhancing tumors showed relevant rates of response $(18 \%$ objective response rate, with a tumor volume reduction as the best response in $17 / 22$ patients), while no objective responses were seen in enhancing tumor patients [47].

Based on these results, and other data suggesting that the IDH mutation may not be necessary for tumor maintenance in advanced phases of glioma progression [99-101], the use of IDH inhibitors is currently tested in earlier disease stages. INDIGO trial (NCT04164901, currently recruiting) is a phase 3 study that will evaluate vorasidenib in the setting of residual or recurrent, non-enhancing grade 2 IDH1/2 mutated gliomas after surgery only.

Other approaches are evaluating the effects of the IDH mutation and accumulation of D2HG on tumor immune microenvironment, and how to exploit them therapeutically. IDH mutated tumors show less tumor infiltrating lymphocytes (TIL) compared to the IDH wildtype counterpart [102], and escape to natural killer cells via the epigenetic silencing of the NKG2D ligands [103]. Furthermore, D2HG produced by tumor cells may act as a paracrine signal that inhibits TIL activity [104]. The inhibition of IDH mutated enzyme activity could thus reverse, at least partially, local immunosuppression. A phase II study of the ivosidenib-nivolumab association in advanced IDH1 mutated solid tumors, including contrast-enhancing gliomas, is recruiting (NCT04056910) (Table 2).

Demethylating agents, such as azacytidine or decitabine, may reverse the hypermethylator phenotype and promote cells differentiation [94,95]. A phase II trial with subcutaneous administration of azacytidine (AGIR; NCT03666559) is ongoing in recurrent grade II and III IDH mutated gliomas (Table 2). Results are awaited.

\section{Immunotherapy}

High grade gliomas are known to induce an immunosuppressive microenvironment, with a low, dysfunctional lymphocytic infiltration and a prevalence of immunosuppressive, protumoral myeloid cells, in an immune-privileged environment, such as the CNS [105,106]. Conspicuous efforts have been made to therapeutically reverse this "cold" immune phenotype, although with modest results to date. Preclinical studies of ICIs showed a promising signal of oncological activity in gliomas [107]. Nonetheless, recent clinical trials failed to show proof of efficacy. The use of the anti-programmed cell death protein 1 (PD1) nivolumab failed to show a survival benefit compared to bevacizumab in recurrent GBM 
in phase III trial Checkmate-143 (ref. [108]). Similarly, the two phase III trials (Checkmate498 and 548) investigating nivolumab in the first-line setting (MGMT-unmethylated and MGMT-methylated GBM, respectively) did not show benefits in terms of progression-free and overall survival $[35,36]$. Several mechanisms have been hypothesized to account for glioma resistance to ICI treatment $[105,109]$. These include, among others, a profound, irreversible $\mathrm{T}$ cell dysfunction, with the upregulation of alternative immune checkpoints (such as TIM3, TIGIT, LAG3) at baseline or as escape mechanisms to ICIs. Furthermore, glioma patients are often in a state of systemic immunosuppression, due to conventional treatments (such as glucocorticoids, radiation therapy, and temozolomide) [110,111], but also to the effects of the tumor itself [112]. The immune-privileged intracranial location could also be of relevance, although clinical benefit has been obtained from ICI in the treatment of brain metastases [113]. Ongoing trials are evaluating different strategies to improve ICI results in glioma patients. A phase I evaluating the feasibility of the anti-LAG3 relatlimab (BMS-986016) with or without nivolumab in recurrent GBM completed accrual, results are awaited (NCT02658981). Indoleamine 2,3-dioxygenase 1 (IDO) is an enzyme produced by GBM TME implicated in the impairment of cytotoxic T lymphocytes functions and upregulation of Tregs [114]. Phase I-II trials are ongoing to evaluate the combination of different IDO inhibitors and anti-PD1 compounds (NCT03532295, NCT04047706) (Table 2). The timing of ICI administration is also under active evaluation, as some results suggest a clinical benefit from the neoadjuvant administration of anti-PD1 pembrolizumab [115].

Tumors with microsatellite instability (MSI) exhibit a large number of somatic mutations (whereas GBM has typically a low mutation rate [116]) and are thought to be more sensitive to ICI treatment via the increased transcription of tumoral neoantigens. The success of pembrolizumab in cancers with microsatellite instability paved the way for its investigation in gliomas with MSI. This was one of the first successes of a basket trial, targeting tumors with MSI regardless of the histological type [117], that resulted in tissueagnostic FDA approval of pembrolizumab in MSI-high cancers. Pembrolizumab has been subsequently FDA-approved for tissue-agnostic treatment of tumors with a high mutational burden (TMB-H, conventionally considered as $>10$ mutations per megabase) irrespectively of microsatellite status, based on the positive results of KEYNOTE-158 trial [118]. Nonetheless, the benefit of ICI treatment in TMB-H gliomas is less clear [119,120]. Gliomas rarely (e.g., $<2 \%$ of cases) present a TMB-H (or "hypermutated") phenotype at diagnosis ("de novo" hypermutated), but often acquire a hypermutated status at recurrence after standard temozolomide treatment ("acquired" hypermutation) [119], mostly through defective mismatch repair (MMR) system $[119,121]$. Interestingly, a recent study suggests that TMB-H cancers most likely to respond to ICI treatments are those with a relevant CD8+ lymphocytic infiltration [122]. Hypermutated gliomas were among those with a reduced CD8+ infiltration. Indeed, two recent studies, albeit with limited sample sizes, did not show a clear clinical benefit of ICI treatment in (mostly acquired) hypermutated gliomas [119,123]. De novo hypermutated glioma patients may experience an increased benefit from ICI [124], but further evidence is required. Clinical trials are ongoing to prospectively evaluate the role of ICI treatment in hypermutated gliomas (e.g., NCT04145115, Table 2).

\section{CAR T Cells Therapy}

Chimeric antigen receptor (CAR) $\mathrm{T}$ cells (CART) are engineered $\mathrm{T}$ lymphocytes expressing synthetic receptors (CARs) that allow the recognition of specific molecules and $T$ cell activation in an HLA-unrestricted manner [125]. First-generation CARs are composed of an extracellular domain responsible for antigen recognition, a transmembrane domain, and an intracellular domain including the $\mathrm{CD} 3 \zeta$ chain transducing $\mathrm{T}$ cell activation. Further modifications resulted from the addition of one (second-generation CARs) or more (third-generation CARs) intracellular costimulatory domains such as CD28 or 4-1BB. Fourth-generation CARs, after recognition of the target antigen, can induce the engineered lymphocyte to express proinflammatory cytokines, bi-specific $\mathrm{T}$ cell engagers (BiTEs), or other genes of interest [126,127]. 
The use of CART targeting tumor-expressed antigens (as CD19) led to remarkable results in hematologic malignancies [125]. Conversely, however, to date, clinical trials exploring CART in GBM patients led to only anecdotally benefits [128] while in most cases they did not show evidence of relevant antitumor effects [129-132] and arose not-negligible safety issues [131]. Therapeutic targets tested in initial phase I/II trials included interleukin13 receptor subunit alpha-2 (IL-13R $\alpha 2)$ [128,129], EGFRvIII [130,131], and human epidermal growth factor receptor 2 (HER2) [132], chosen because of the selective expression in tumor cells compared to healthy brain cells. In the cited clinical trials, IL-13R $\alpha 2$-directed CART was infused into the surgical cavity after resection of recurrent GBM, whereas EGFRvIIIand HER2-directed CART were administered intravenously. Little or no clinically relevant benefit was seen in most cases, despite analysis of re-resected tumors confirmed in situ trafficking of intravenously infused EGFRvIII-directed CAR T-cells [130]. A notable clinical response has been reported after intraventricular infusion of IL-13R $\alpha 2$-directed CART in a patient with multifocal craniospinal recurrent GBM [128]. The observed benefit lasted 7.5 months, but the tumor eventually relapsed [128].

Several mechanisms have been evoked for these disappointing results. Firstly, tumor cells may escape CART losing the expression of the targeted molecule. Indeed, antigen loss has been demonstrated in tumors treated with IL-13R $\alpha 2$ - and EGFRvIII-directed CART $[129,130]$. It is unclear if this has been induced by administered treatments or representing the natural evolution of the disease, as EGFRvIII loss may occur even in the absence of EGFRvIII-directed treatments [91]. The intrinsic intratumor heterogeneity of GBM under therapeutical pressure could lead also to the selection of subclones lacking the expression of the molecule of interest. Furthermore, tumor specimens obtained from CARTtreated patients display increased expression of coinhibitory molecules and increased Treg infiltration [130]. Finally, it should not be underscored that CART therapy is not devoid of potentially detrimental side effects [133], including neurological toxicity [134]. In the NCT01454596 trial, two patients developed respiratory failure shortly after intravenous administration of EGFRvIII-directed CART, and one died [131].

New approaches to overcome the discussed shortcomings include the utilization of new-gen CART, and the exploration of novel targets [126]. In this regard, the Brown group identified chlorotoxin (CLTX), a peptide derived from scorpion venom, as a promising tumor-binding peptide to be incorporated in CAR as the antigen-recognizing domain [135]. CLTX was demonstrated to bind the majority of tumor cells in more than $90 \%$ of tested tumor samples, with little to no reactivity with healthy brain and independently from the expression of other targets as IL-13R $\alpha 2$, EGFRvIII, and HER2 (ref. [135]). CLTX-CART demonstrated promising activity in in vitro and murine glioma models [135] and is currently under investigation in a phase I trial (NCT04214392) (Table 2). Nonetheless, the same authors demonstrated that the expression of matrix-metalloproteinase 2 (MMP2) is required for an efficient tumor targeting of CLTX-CART [135]. Such as, it has been anticipated that loss of MMP2 in GBM cells could represent a tumor escape mechanism [127]. Results are awaited. Other strategies aim at targeting multiple tumor-associated antigens in order to overcome GBM heterogeneity. Ahmed and colleagues developed "universal" CAR (UCAR) co-targeting HER2, IL13R $\alpha 2$, and ephrin A receptor 2 (EphA2), with promising preclinical results [136] but no clinical data available to date. Finally, a GBM-directed synNotch CART has been recently developed [137]. SynNotch receptors are engineered transmembrane receptors that after the recognition of the target antigen activates the expression of a specific transcript. Choe et al. recently reported engineered $\mathrm{T}$ lymphocytes that can conditionally express EphA2 and IL13R $\alpha 2$-directed CAR under the control of a synNotch receptor recognizing both a tumor-specific but heterogeneous antigen (EGFRvIII) or an organ-specific antigen (myelin oligodendrocyte glycoprotein, or MOG) [137]. In patient-derived tumor xenograft, both EGFRvIII and MOG-directed synNotch-CART displayed higher antitumor effects, with reduced exhaustion, and no evidence of off-tumor killing [137]. 


\section{Gene Therapy and Virotherapy Approaches \\ 10.1. Gene Therapy}

The term "gene therapy" indicates the administration of exogenous genetic material as a therapeutical intervention [138-140]. In cancer, it can be used to reactivate the expression of lost tumor suppressor genes, inhibit aberrantly activated oncogenes, or induce the expression of immunostimulatory molecules or suicide enzymes, the latter converting a non-toxic compound into a cytotoxic molecule [138-140]. Vectors that can deliver the genetic material to target cells include viruses (adenoviruses, retroviruses, lentiviruses), non-polymeric, and polymeric nanoparticles (as liposomes) [138]. A widely studied gene therapy approach in gliomas is the induction of the expression of suicide genes. One example is the herpes simplex virus thymidine kinase (HSV-TK) enzyme that renders cells sensible to ganciclovir prodrug [139]. A first phase III study using a retroviral vector in newly diagnosed HGG failed to show an increased survival in patients transduced with HSV-TK [141]; treatment failure has been associated with inefficient gene transduction. Subsequent phase II-III trials assessing adenoviral vectors [142-144] disclosed more favorable results and suggested that patients that receive a gross total resection are more likely to benefit from the treatment [143]. Another suicide gene codes for the cytosine deaminase (CDA) enzyme that can convert systemically delivered non-toxic 5-fluorocytosine into cytotoxic compound 5-fluorouracil [139]. An extensively explored vector is Toca-511 retrovirus, that is characterized by a retained replicating capacity. Other than causing the expression of CDA in target cells, Toca-511 seems able to partially reverse the local immunosuppression in gliomas [145]. Despite promising results in the setting of recurrent high grade gliomas in the phase II trial [146], a subsequent phase III study failed to show a survival benefit in transduced cases compared to the standard of care [147]. A further strategy relies on the local induction of expression of proinflammatory, antitumor cytokines, such as interferon $\beta$ or $\gamma$ or interleukin-12 (IL12). IL12, in particular, is a potent anticancer cytokine, but its systemic use is severely limited by relevant side effects. The local administration of an adenoviral vector (Ad-RTS-hIL-12) that induces the expression of IL12 under the control of an oral activator (veledimex) was acceptably safe and showed signs of efficacy in a recent phase I trial [148]. Re-resected tumors displayed increased CD8+ lymphocytes, mostly expressing PD1. This provided the rationale for a combinatorial approach testing the association of the Ad-RTS-hIL-12 gene therapy with the anti-PD1 nivolumab [149]. In the phase I trial, the combination displayed no additional toxicity compared to IL12 gene monotherapy [149], and a phase II trial (NCT04006119, Table 2) has been completed, results are awaited. Gene therapy can be used also to target protumoral cells in the tumor microenvironment. A remarkable example is VB-111, that uses an adenoviral vector to transduce a chimeric gene coding for a protein composed of the extracellular domain of the tumor necrosis factor (TNF) receptor 1 and an intracellular derived from Fas protein [139]. Under TNF stimulation, the chimeric protein elicits cellular apoptosis. Its expression can be limited to proliferating endothelial cells using a modified preproendothelin promoter [139]. Of note, differing from most gene therapy vectors targeting tumor cells that are administered locally in the surgical cavity, VB-111 is administered intravenously. Treatment with VB-111 showed to be safe in a phase I/II trial that enrolled recurrent GBM patients [150]. Furthermore, patients in the primed combination group (receiving VB-111 monotherapy at inclusion and switched to bevacizumab plus VB-111 continuation at tumor progression) displayed promising median overall survival (414 days) and 12-month survival rate (57\%) [150]. Nonetheless, a subsequent phase III trial testing the combination of VB-111 plus bevacizumab failed to showed a survival benefit compared to bevacizumab alone [151]. It has been hypothesized that the lack of VB-111 monotherapy priming could explain for the absence of survival benefit seen in the primed combination subgroup in phase I/II trial [151]. A new phase II randomized, placebo-controlled trial (NCT04406272, Table 2) is currently ongoing to evaluate the utility of VB-111 in the neoadjuvant setting of recurrent glioblastoma (presurgical versus postsurgical administration). 


\subsection{Oncolytic Viruses}

Oncolytic viruses are engineered or naturally oncoselective viruses that infect, replicate, and lyse tumor cells releasing new progeny capable to infect neighbor cells $[138,140]$. By infecting and lysing cells, they can also stimulate local immune responses. One of the most studied oncolytic viruses is human herpes virus type 1 (HSV1). A seminal work by Martuza and colleagues demonstrated that attenuated HSV1 can retain oncolytic activity while being unable to replicate in non-dividing cells as healthy neurons [152]. Further engineered HSV1 as HSV1716 (with deletion of the $\gamma 34.5$ gene) and G207 (with deletion of the $U_{L} 39$ gene) display increased oncolytic selectivity $[138,140]$. Phase I trials in recurrent glioma patients demonstrated a good safety profile and feasibility, with evidence of viral replication in tumor cells [153-156]. Another oncolytic virus clinically tested in glioma patients is DNX-2401, a modified human adenovirus that selectively infects cells with impaired retinoblastoma pathway (a common oncogenic alteration seen in glioblastoma [7]). A recent phase I trial of intratumoral administration of DNX-2401 for recurrent malignant glioma demonstrated promising results in terms of sustained clinical responses (five out of 25 patients survived more than three years, with a $>95 \%$ tumor response in three) [157]. A phase II combination trial of DNX-2401 plus pembrolizumab (KEYNOTE-192 CAPTIVE, NCT02798406) complete accrual. The first results, presented in abstract form, are promising in terms of safety and antitumoral activity $[158,159]$, and a phase III trial is awaited.

\subsection{Combinatory Approaches}

It has been postulated that virotherapy efficacy may be limited by incomplete transduction of the target mass in greater lesions [160]. To counteract this shortcoming, combination therapies have been developed that bring together the conditional cytotoxic and immunestimulatory approaches $[138,160]$. The concomitant administration of an adenoviral vector expressing HSV-TK (Ad-TK) that renders transduced cells sensitive to ganciclovir and an adenoviral vector expressing Flt3L (Ad-Flt3L), a small molecule crucial for dendritic cells (DC) development, has been shown to have synergistic effects [161]. Preclinical models demonstrated that, after Ad-TK + Ad-Flt3L treatment, DC are activated by damageassociated molecular pattern molecules as HMGB1 and after uptake of tumor antigens from dying cells they prime a systemic immune response [162]. Tumor responses can be further increased combining Ad-TK + Ad-Flt3L treatment with DC vaccination [163] or ICI [164]. A phase I clinical trial of Ad-TK + Ad-Flt3L treatment for newly diagnosed malignant glioma (NCT01811992) has been completed. Interim analyses showed an acceptable safety profile, with evidence of increased inflammatory infiltrate in re-resected tumors [165].

\section{Blood-Brain Barrier Disruption by Pulsed Ultrasound}

The intratumoral delivery of systemically administered therapies may be limited by the present because of the intracranial location of gliomas, particularly for infiltrative regions where the blood-brain barrier (BBB) is mostly intact. The intracranial drug delivery may be increased by disrupting the BBB using new physical methods such as low-intensity pulsed ultrasound (LIPU) in combination with systemic administration of micron-sized bubbles [166]. LIPU has proven to disrupt the BBB [167] (Figure 3) and increase the intracerebral concentrations of systemically administered antitumoral compounds [168].

LIPU has furthermore been shown to enhance survival in preclinical glioma models [170] and to be safe in long-term studies in nonhuman primates [171]. A recent phase 1 study evaluated the safety and feasibility of an intracranial ultrasound device (SonoCloud1) used to disrupt the BBB and increase carboplatin delivery [48]. BBB disruption was visible on post-treatment T1-weighted MRI scans for most of the sonications performed. Repeated sonications in some patients resulted in tumor reduction in the field of the implant [48]. Treatment-related adverse events (transient cerebral oedema) were transient and manageable, without carboplatin-related neurotoxicity. Patients with BBB disruption clearly visible on MRI had increased PFS and OS compared with patients without evidence of BBB disruption [48]. The phase I/II study Sonocloud-9 treating recurrent GBM patients with 
LIPU and carboplatine (NCT03744026) completed accrual, and results are awaited. Phase II SonoFIRST study (NCT04614493) is currently enrolling newly diagnosed GBM patients to be treated with LIPU plus concurrent chemoradiation and adjuvant temozolomide.

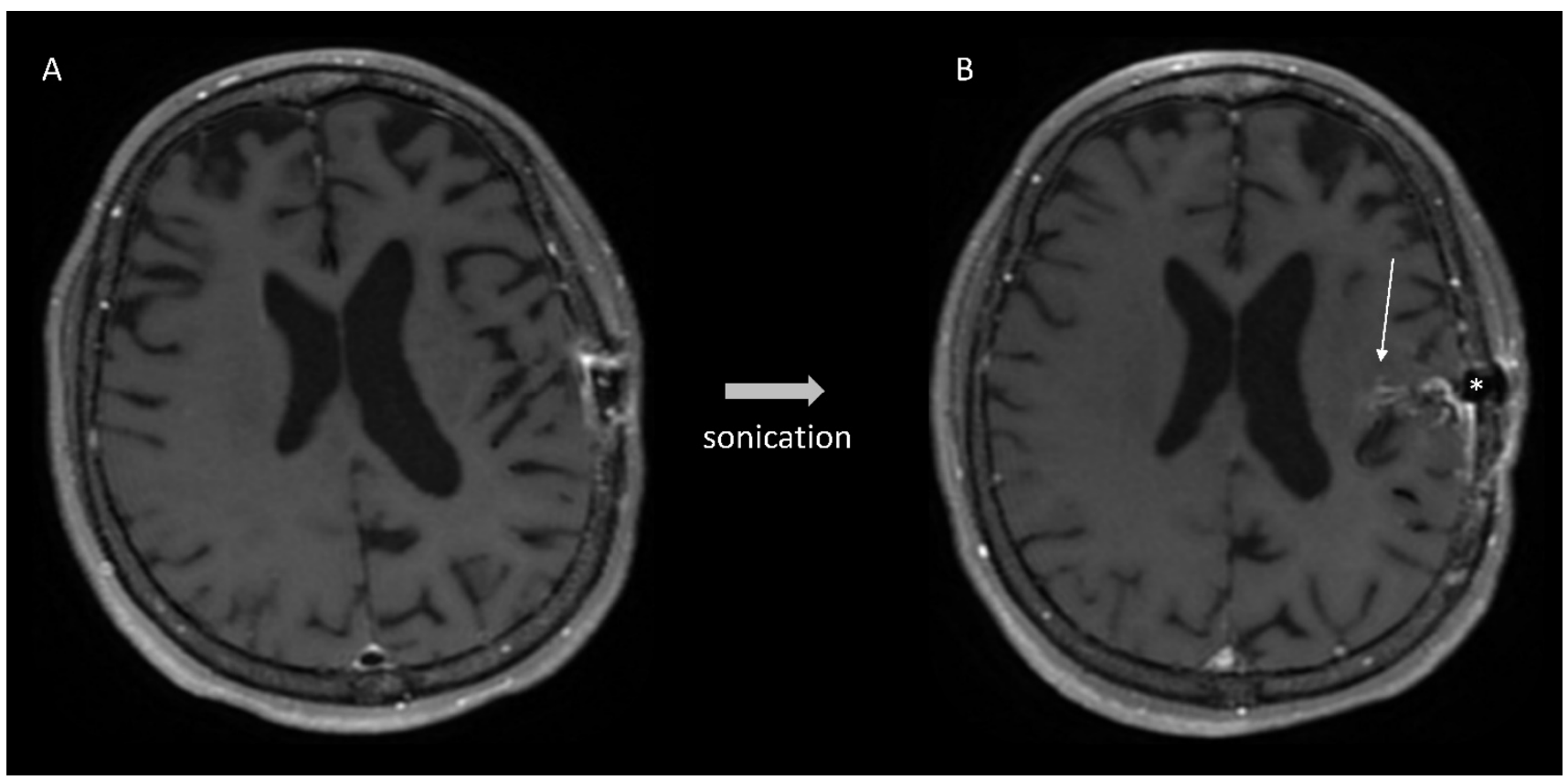

Figure 3. Adult patient with recurrent glioblastoma before (Panel A) and after (Panel B) sonication using the Sonocloud device (star) implanted in the skull. In (Panel B), contrast enhancement (arrow) indicates ultrasound mediated blood-brain barrier opening. Case already published in ref. [169].

\section{Conclusions}

The efficacy of conventional antineoplastic treatments remains very limited in patients with malignant gliomas. Many targeted approaches validated in general oncology have been tested also in neuro-oncology, with variable results. Activating molecular alterations of current therapeutic relevance remain infrequent but may greatly impact patients' management when present. Similarly, while revolutionizing the therapeutic scenario in several advanced cancers, immunotherapies did not show a clear clinical benefit in the diffuse glioma setting. Several new approaches to increase their efficacy are currently under investigation. Hypermutated gliomas (both de novo and treatment-induced) may be most likely to benefit from ICI treatments, although this remains a matter of discussion. These observations encourage to systematically screen for druggable alterations and a hypermutated status since the initial diagnosis and to discuss surgery at recurrence in order to obtain new specimens to be tested for. New methods, such as pulsed ultrasound to disrupt the blood-brain barrier, gene therapy, and oncolytic virotherapy, are well tolerated and may be included in the therapeutic armamentarium soon.

Author Contributions: Conceptualization, A.L.D.S., D.G., A.P. and G.L.; writing-original draft preparation, A.L.D.S., D.G., A.P., M.C., G.L., O.S.S., A.I. and C.B.; writing-review and editing, A.L.D.S., D.G., A.P., M.C., G.L., O.S.S., A.I., C.B., A.C. and A.G.N. All authors have read and agreed to the published version of the manuscript.

Funding: This research received no external funding.

Acknowledgments: A.P. and A.L.D.S. are grateful to Premio Carla Russo and Palummo family for their support. A.P. receives support from "Fondation pour la Recherche Médicale" (grant FDM202106013569) independently from this work.

Conflicts of Interest: The authors declare no conflict of interest. 


\section{References}

1. Ostrom, Q.T.; Patil, N.; Cioffi, G.; Waite, K.; Kruchko, C.; Barnholtz-Sloan, J.S. CBTRUS Statistical Report: Primary Brain and Other Central Nervous System Tumors Diagnosed in the United States in 2013-2017. Neuro-Oncology 2020, 22, iv1-iv96. [CrossRef] [PubMed]

2. Darlix, A.; Zouaoui, S.; Rigau, V.; Bessaoud, F.; Figarella-Branger, D.; Mathieu-Daudé, H.; Trétarre, B.; Bauchet, F.; Duffau, H.; Taillandier, L.; et al. Epidemiology for Primary Brain Tumors: A Nationwide Population-Based Study. J. Neurooncol. 2017, 131, 525-546. [CrossRef] [PubMed]

3. Crocetti, E.; Trama, A.; Stiller, C.; Caldarella, A.; Soffietti, R.; Jaal, J.; Weber, D.C.; Ricardi, U.; Slowinski, J.; Brandes, A. Epidemiology of Glial and Non-Glial Brain Tumours in Europe. Eur. J. Cancer 2012, 48, 1532-1542. [CrossRef] [PubMed]

4. Louis, D.N.; Perry, A.; Wesseling, P.; Brat, D.J.; Cree, I.A.; Figarella-Branger, D.; Hawkins, C.; Ng, H.K.; Pfister, S.M.; Reifenberger, G.; et al. The 2021 WHO Classification of Tumors of the Central Nervous System: A Summary. Neuro-Oncology 2021, 23, 1231-1251. [CrossRef]

5. Stupp, R.; Hegi, M.E.; Mason, W.P.; van den Bent, M.J.; Taphoorn, M.J.; Janzer, R.C.; Ludwin, S.K.; Allgeier, A.; Fisher, B.; Belanger K.; et al. Effects of Radiotherapy with Concomitant and Adjuvant Temozolomide versus Radiotherapy Alone on Survival in Glioblastoma in a Randomised Phase III Study: 5-Year Analysis of the EORTC-NCIC Trial. Lancet Oncol. 2009, 10, 459-466. [CrossRef]

6. McLendon, R.; Friedman, A.; Bigner, D.; Van Meir, E.G.; Brat, D.J.; Mastrogianakis, G.M.; Olson, J.J.; Mikkelsen, T.; Lehman, N.; Aldape, K.; et al. Comprehensive Genomic Characterization Defines Human Glioblastoma Genes and Core Pathways. Nature 2008, 455, 1061-1068. [CrossRef]

7. Brennan, C.W.; Verhaak, R.G.W.; McKenna, A.; Campos, B.; Noushmehr, H.; Salama, S.R.; Zheng, S.; Chakravarty, D.; Sanborn, J.Z.; Berman, S.H.; et al. The Somatic Genomic Landscape of Glioblastoma. Cell 2013, 155, 462-477. [CrossRef]

8. Yan, H.; Parsons, D.W.; Jin, G.; McLendon, R.; Rasheed, B.A.; Yuan, W.; Kos, I.; Batinic-Haberle, I.; Jones, S.; Riggins, G.J.; et al. IDH1 and IDH2 Mutations in Gliomas. N. Engl. J. Med. 2009, 360, 765-773. [CrossRef]

9. Comprehensive, Integrative Genomic Analysis of Diffuse Lower-Grade Gliomas. N. Engl. J. Med. 2015, 372, 2481-2498. [CrossRef]

10. Capper, D.; Jones, D.T.W.; Sill, M.; Hovestadt, V.; Schrimpf, D.; Sturm, D.; Koelsche, C.; Sahm, F.; Chavez, L.; Reuss, D.E.; et al. DNA Methylation-Based Classification of Central Nervous System Tumours. Nature 2018, 555, 469-474. [CrossRef]

11. Fanelli, G.N.; Naccarato, A.G.; Scatena, C. Recent Advances in Cancer Plasticity: Cellular Mechanisms, Surveillance Strategies, and Therapeutic Optimization. Front. Oncol. 2020, 10, 569. [CrossRef] [PubMed]

12. Louis, D.N.; Ohgaki, H.; Wiestler, O.D.; Cavenee, W.K.; Burger, P.C.; Jouvet, A.; Scheithauer, B.W.; Kleihues, P. The 2007 WHO Classification of Tumours of the Central Nervous System. Acta Neuropathol. 2007, 114, 97-109. [CrossRef] [PubMed]

13. Eckel-Passow, J.E.; Lachance, D.H.; Molinaro, A.M.; Walsh, K.M.; Decker, P.A.; Sicotte, H.; Pekmezci, M.; Rice, T.; Kosel, M.L.; Smirnov, I.V.; et al. Glioma Groups Based on 1p/19q, IDH, and TERT Promoter Mutations in Tumors. N. Engl. J. Med. 2015, 372, 2499-2508. [CrossRef] [PubMed]

14. Appay, R.; Dehais, C.; Maurage, C.-A.; Alentorn, A.; Carpentier, C.; Colin, C.; Ducray, F.; Escande, F.; Idbaih, A.; Kamoun, A.; et al. CDKN2A Homozygous Deletion Is a Strong Adverse Prognosis Factor in Diffuse Malignant IDH-Mutant Gliomas. Neuro-Oncology 2019, 21, 1519-1528. [CrossRef] [PubMed]

15. Louis, D.N.; Perry, A.; Reifenberger, G.; von Deimling, A.; Figarella-Branger, D.; Cavenee, W.K.; Ohgaki, H.; Wiestler, O.D.; Kleihues, P.; Ellison, D.W. The 2016 World Health Organization Classification of Tumors of the Central Nervous System: A Summary. Acta Neuropathol. 2016, 131, 803-820. [CrossRef]

16. Brat, D.J.; Aldape, K.; Colman, H.; Figrarella-Branger, D.; Fuller, G.N.; Giannini, C.; Holland, E.C.; Jenkins, R.B.; KleinschmidtDeMasters, B.; Komori, T.; et al. CIMPACT-NOW Update 5: Recommended Grading Criteria and Terminologies for IDH-Mutant Astrocytomas. Acta Neuropathol. 2020, 139, 603-608. [CrossRef]

17. Berzero, G.; Di Stefano, A.L.; Ronchi, S.; Bielle, F.; Villa, C.; Guillerm, E.; Capelle, L.; Mathon, B.; Laurenge, A.; Giry, M.; et al. IDH-Wildtype Lower-Grade Diffuse Gliomas: The Importance of Histological Grade and Molecular Assessment for Prognostic Stratification. Neuro-Oncology 2020, 23, 955-966. [CrossRef]

18. Brat, D.J.; Aldape, K.; Colman, H.; Holland, E.C.; Louis, D.N.; Jenkins, R.B.; Kleinschmidt-DeMasters, B.K.; Perry, A.; Reifenberger, G.; Stupp, R.; et al. CIMPACT-NOW Update 3: Recommended Diagnostic Criteria for “Diffuse Astrocytic Glioma, IDH-Wildtype, with Molecular Features of Glioblastoma, WHO Grade IV". Acta Neuropathol. 2018, 136, 805-810. [CrossRef]

19. Weller, M.; van den Bent, M.; Preusser, M.; Le Rhun, E.; Tonn, J.C.; Minniti, G.; Bendszus, M.; Balana, C.; Chinot, O.; Dirven, L.; et al. EANO Guidelines on the Diagnosis and Treatment of Diffuse Gliomas of Adulthood. Nat. Rev. Clin. Oncol. 2021, 18, 170-186. [CrossRef]

20. Wen, P.Y.; Weller, M.; Lee, E.Q.; Alexander, B.M.; Barnholtz-Sloan, J.S.; Barthel, F.P.; Batchelor, T.T.; Bindra, R.S.; Chang, S.M.; Chiocca, E.A.; et al. Glioblastoma in Adults: A Society for Neuro-Oncology (SNO) and European Society of Neuro-Oncology (EANO) Consensus Review on Current Management and Future Directions. Neuro-Oncology 2020, 22, 1073-1113. [CrossRef]

21. Stupp, R.; Mason, W.P.; van den Bent, M.J.; Weller, M.; Fisher, B.; Taphoorn, M.J.B.; Belanger, K.; Brandes, A.A.; Marosi, C.; Bogdahn, U.; et al. Radiotherapy plus Concomitant and Adjuvant Temozolomide for Glioblastoma. N. Engl. J. Med. 2005, 352, 987-996. [CrossRef] [PubMed] 
22. Perry, J.R.; Laperriere, N.; O'Callaghan, C.J.; Brandes, A.A.; Menten, J.; Phillips, C.; Fay, M.; Nishikawa, R.; Cairncross, J.G.; Roa, W.; et al. Short-Course Radiation plus Temozolomide in Elderly Patients with Glioblastoma. N. Engl. J. Med. 2017, 376, 1027-1037. [CrossRef] [PubMed]

23. Pérez-Larraya, J.G.; Ducray, F.; Chinot, O.; Catry-Thomas, I.; Taillandier, L.; Guillamo, J.-S.; Campello, C.; Monjour, A.; CartalatCarel, S.; Barrie, M.; et al. Temozolomide in Elderly Patients with Newly Diagnosed Glioblastoma and Poor Performance Status: An ANOCEF Phase II Trial. J. Clin. Oncol. 2011, 29, 3050-3055. [CrossRef] [PubMed]

24. Wick, W.; Platten, M.; Meisner, C.; Felsberg, J.; Tabatabai, G.; Simon, M.; Nikkhah, G.; Papsdorf, K.; Steinbach, J.P.; Sabel, M.; et al. Temozolomide Chemotherapy Alone versus Radiotherapy Alone for Malignant Astrocytoma in the Elderly: The NOA-08 Randomised, Phase 3 Trial. Lancet Oncol. 2012, 13, 707-715. [CrossRef]

25. Cairncross, G.; Wang, M.; Shaw, E.; Jenkins, R.; Brachman, D.; Buckner, J.; Fink, K.; Souhami, L.; Laperriere, N.; Curran, W.; et al. Phase III Trial of Chemoradiotherapy for Anaplastic Oligodendroglioma: Long-Term Results of RTOG 9402. J. Clin. Oncol. 2013, 31, 337-343. [CrossRef]

26. Van den Bent, M.J.; Brandes, A.A.; Taphoorn, M.J.B.; Kros, J.M.; Kouwenhoven, M.C.M.; Delattre, J.-Y.; Bernsen, H.J.J.A.; Frenay, M.; Tijssen, C.C.; Grisold, W.; et al. Adjuvant Procarbazine, Lomustine, and Vincristine Chemotherapy in Newly Diagnosed Anaplastic Oligodendroglioma: Long-Term Follow-up of EORTC Brain Tumor Group Study 26951. J. Clin. Oncol. 2013, 31, 344-350. [CrossRef]

27. Van den Bent, M.; Baumert, B.; Erridge, S.C.; Vogelbaum, M.A.; Nowak, A.K.; Sanson, M.; Brandes, A.A.; Clement, P.M.; Baurain, J.F.; Mason, W.P.; et al. Interim Results from the CATNON Trial (EORTC Study 26053-22054) of Treatment with Concurrent and Adjuvant Temozolomide for 1p/19q Non-Co-Deleted Anaplastic Glioma: A Phase 3, Randomised, Open-Label Intergroup Study. Lancet 2017, 390, 1645-1653. [CrossRef]

28. Buckner, J.C.; Shaw, E.G.; Pugh, S.L.; Chakravarti, A.; Gilbert, M.R.; Barger, G.R.; Coons, S.; Ricci, P.; Bullard, D.; Brown, P.D.; et al. Radiation plus Procarbazine, CCNU, and Vincristine in Low-Grade Glioma. N. Engl. J. Med. 2016, 374, 1344-1355. [CrossRef]

29. Van Den Bent, M.J.; Erridge, S.; Vogelbaum, M.A.; Nowak, A.K.; Sanson, M.; Brandes, A.A.; Wick, W.; Clement, P.M.; Baurain, J.-F.; Mason, W.P.; et al. Second Interim and First Molecular Analysis of the EORTC Randomized Phase III Intergroup CATNON Trial on Concurrent and Adjuvant Temozolomide in Anaplastic Glioma without 1p/19q Codeletion. J. Clin. Oncol. 2019, 37, 2000. [CrossRef]

30. Hegi, M.E.; Diserens, A.-C.; Gorlia, T.; Hamou, M.-F.; de Tribolet, N.; Weller, M.; Kros, J.M.; Hainfellner, J.A.; Mason, W.; Mariani, L.; et al. MGMT Gene Silencing and Benefit from Temozolomide in Glioblastoma. N. Engl. J. Med. 2005, 352, 997-1003. [CrossRef]

31. Weller, M.; Stupp, R.; Reifenberger, G.; Brandes, A.A.; van den Bent, M.J.; Wick, W.; Hegi, M.E. MGMT Promoter Methylation in Malignant Gliomas: Ready for Personalized Medicine? Nat. Rev. Neurol. 2010, 6, 39-51. [CrossRef] [PubMed]

32. Reifenberger, G.; Hentschel, B.; Felsberg, J.; Schackert, G.; Simon, M.; Schnell, O.; Westphal, M.; Wick, W.; Pietsch, T.; Loeffler, M.; et al. Predictive Impact of MGMT Promoter Methylation in Glioblastoma of the Elderly. Int. J. Cancer 2012, 131, 1342-1350. [CrossRef] [PubMed]

33. Montemurro, N.; Fanelli, G.N.; Scatena, C.; Ortenzi, V.; Pasqualetti, F.; Mazzanti, C.M.; Morganti, R.; Paiar, F.; Naccarato, A.G.; Perrini, P. Surgical Outcome and Molecular Pattern Characterization of Recurrent Glioblastoma Multiforme: A Single-Center Retrospective Series. Clin. Neurol. Neurosurg. 2021, 207, 106735. [CrossRef] [PubMed]

34. Malmström, A.; Grønberg, B.H.; Marosi, C.; Stupp, R.; Frappaz, D.; Schultz, H.; Abacioglu, U.; Tavelin, B.; Lhermitte, B.; Hegi, M.E.; et al. Temozolomide versus Standard 6-Week Radiotherapy versus Hypofractionated Radiotherapy in Patients Older than 60 Years with Glioblastoma: The Nordic Randomised, Phase 3 Trial. Lancet Oncol. 2012, 13, 916-926. [CrossRef]

35. Bristol-Myers Squibb A Randomized Phase 3 Single Blind Study of Temozolomide Plus Radiation Therapy Combined with Nivolumab or Placebo in Newly Diagnosed Adult Subjects with MGMT-Methylated (Tumor O6-Methylguanine DNA Methyltransferase) Glioblastoma. 2020. Available online: clinicaltrials.gov (accessed on 29 December 2021).

36. Bristol-Myers Squibb A Randomized Phase 3 Open Label Study of Nivolumab vs. Temozolomide Each in Combination with Radiation Therapy in Newly Diagnosed Adult Subjects with Unmethylated MGMT (Tumor O-6-Methylguanine DNA Methyltransferase) Glioblastoma (CheckMate 498: CHECKpoint Pathway and Nivolumab Clinical Trial Evaluation 498 ). 2021. Available online: clinicaltrials.gov (accessed on 29 December 2021).

37. Weller, M.; Le Rhun, E. How Did Lomustine Become Standard of Care in Recurrent Glioblastoma? Cancer Treat. Rev. 2020, 87, 102029. [CrossRef]

38. Wick, W.; Gorlia, T.; Bendszus, M.; Taphoorn, M.; Sahm, F.; Harting, I.; Brandes, A.A.; Taal, W.; Domont, J.; Idbaih, A.; et al. Lomustine and Bevacizumab in Progressive Glioblastoma. N. Engl. J. Med. 2017, 377, 1954-1963. [CrossRef]

39. Lombardi, G.; De Salvo, G.L.; Brandes, A.A.; Eoli, M.; Ruda, R.; Faedi, M.; Lolli, I.; Pace, A.; Daniele, B.; Pasqualetti, F.; et al. Regorafenib Compared with Lomustine in Patients with Relapsed Glioblastoma (REGOMA): A Multicentre, Open-Label, Randomised, Controlled, Phase 2 Trial. Lancet Oncol. 2019, 20, 110-119. [CrossRef]

40. Indraccolo, S.; De Salvo, G.L.; Verza, M.; Caccese, M.; Esposito, G.; Piga, I.; Del Bianco, P.; Pizzi, M.; Gardiman, M.P.; Eoli, M.; et al. Phosphorylated Acetyl-CoA Carboxylase Is Associated with Clinical Benefit with Regorafenib in Relapsed Glioblastoma: REGOMA Trial Biomarker Analysis. Clin. Cancer Res. 2020, 26, 4478-4484. [CrossRef]

41. Santangelo, A.; Rossato, M.; Lombardi, G.; Benfatto, S.; Lavezzari, D.; De Salvo, G.L.; Indraccolo, S.; Dechecchi, M.C.; Prandini, P.; Gambari, R.; et al. A Molecular Signature Associated with Prolonged Survival in Glioblastoma Patients Treated with Regorafenib. Neuro-Oncology 2021, 23, 264-276. [CrossRef] 
42. Berzero, G.; Bellu, L.; Baldini, C.; Ducray, F.; Guyon, D.; Eoli, M.; Silvani, A.; Dehais, C.; Idbaih, A.; Younan, N.; et al. Sustained Tumor Control with MAPK Inhibition in BRAF V600-Mutant Adult Glial and Glioneuronal Tumors. Neurology 2021, 97, e673-e683. [CrossRef]

43. Boyer, J.; Birzu, C.; Bielle, F.; Goulas, C.; Savatovsky, J.; Karachi, C.; Idbaih, A. Dramatic Response of STRN-NTRK-Fused Malignant Glioneuronal Tumor to Larotrectinib in Adult. Neuro-Oncology 2021, 23, 1200-1202. [CrossRef] [PubMed]

44. Kaley, T.; Touat, M.; Subbiah, V.; Hollebecque, A.; Rodon, J.; Lockhart, A.C.; Keedy, V.; Bielle, F.; Hofheinz, R.D.; Joly, F.; et al. BRAF Inhibition in BRAFV600-Mutant Gliomas: Results From the VE-BASKET Study. J. Clin. Oncol. 2018, 36, 3477-3484. [CrossRef] [PubMed]

45. Wen, P.Y.; Stein, A.; van den Bent, M.; De Greve, J.; Wick, A.; de Vos, F.Y.F.L.; von Bubnoff, N.; van Linde, M.E.; Lai, A.; Prager, G.W.; et al. Dabrafenib plus trametinib in patients with BRAFV600E-mutant low-grade and high-grade glioma (ROAR): A multicentre, open-label, single-arm, phase 2, basket trial. Lancet Oncol. 2022, 23, 53-64. [CrossRef]

46. Mellinghoff, I.K.; Ellingson, B.M.; Touat, M.; Maher, E.; De La Fuente, M.I.; Holdhoff, M.; Cote, G.M.; Burris, H.; Janku, F.; Young, R.J.; et al. Ivosidenib in Isocitrate Dehydrogenase 1-Mutated Advanced Glioma. J. Clin. Oncol. 2020, 38, 3398-3406. [CrossRef]

47. Mellinghoff, I.K.; Penas-Prado, M.; Peters, K.B.; Burris, H.A.; Maher, E.A.; Janku, F.; Cote, G.M.; de la Fuente, M.I.; Clarke, J.L.; Ellingson, B.M.; et al. Vorasidenib, a Dual Inhibitor of Mutant IDH1/2, in Recurrent or Progressive Glioma; Results of a First-in-Human Phase I Trial. Clin. Cancer Res. 2021, 27, 4491-4499. [CrossRef]

48. Idbaih, A.; Canney, M.; Belin, L.; Desseaux, C.; Vignot, A.; Bouchoux, G.; Asquier, N.; Law-Ye, B.; Leclercq, D.; Bissery, A.; et al. Safety and Feasibility of Repeated and Transient Blood-Brain Barrier Disruption by Pulsed Ultrasound in Patients with Recurrent Glioblastoma. Clin. Cancer Res. 2019, 25, 3793-3801. [CrossRef]

49. Schindler, G.; Capper, D.; Meyer, J.; Janzarik, W.; Omran, H.; Herold-Mende, C.; Schmieder, K.; Wesseling, P.; Mawrin, C.; Hasselblatt, M.; et al. Analysis of BRAF V600E Mutation in 1,320 Nervous System Tumors Reveals High Mutation Frequencies in Pleomorphic Xanthoastrocytoma, Ganglioglioma and Extra-Cerebellar Pilocytic Astrocytoma. Acta Neuropathol. 2011, 121, 397-405. [CrossRef]

50. Behling, F.; Barrantes-Freer, A.; Skardelly, M.; Nieser, M.; Christians, A.; Stockhammer, F.; Rohde, V.; Tatagiba, M.; Hartmann, C.; Stadelmann, C.; et al. Frequency of BRAF V600E Mutations in 969 Central Nervous System Neoplasms. Diagn. Pathol. 2016, 11, 1-10. [CrossRef]

51. Flaherty, K.T.; Puzanov, I.; Kim, K.B.; Ribas, A.; McArthur, G.A.; Sosman, J.A.; O’Dwyer, P.J.; Lee, R.J.; Grippo, J.F.; Nolop, K.; et al. Inhibition of Mutated, Activated BRAF in Metastatic Melanoma. N. Engl. J. Med. 2010, 363, 809-819. [CrossRef]

52. Robert, C.; Karaszewska, B.; Schachter, J.; Rutkowski, P.; Mackiewicz, A.; Stroiakovski, D.; Lichinitser, M.; Dummer, R.; Grange, F.; Mortier, L.; et al. Improved Overall Survival in Melanoma with Combined Dabrafenib and Trametinib. N. Engl. J. Med. 2015, 372, 30-39. [CrossRef]

53. Subbiah, V.; Baik, C.; Kirkwood, J.M. Clinical Development of BRAF plus MEK Inhibitor Combinations. Trends Cancer 2020, 6, 797-810. [CrossRef] [PubMed]

54. Touat, M.; Gratieux, J.; Auliac, S.C.; Sejean, K.; Aldea, S.; Savatovsky, J.; Perkins, G.; Blons, H.; Ligon, K.L.; Idbaih, A.; et al. Vemurafenib and Cobimetinib Overcome Resistance to Vemurafenib in BRAF-Mutant Ganglioglioma. Neurology 2018, 91, 523-525. [CrossRef] [PubMed]

55. Di Stefano, A.L.; Guyon, D.; Sejean, K.; Feuvret, L.; Villa, C.; Berzero, G.; Desforges Bullet, V.; Halimi, E.; Boulin, A.; Baussart, B.; et al. Medical Debulking with BRAF/MEK Inhibitors in Aggressive BRAF-Mutant Craniopharyngioma. Neurooncol. Adv. 2020, 2 , vdaa141. [CrossRef] [PubMed]

56. Touat, M.; Ileana, E.; Postel-Vinay, S.; André, F.; Soria, J.-C. Targeting FGFR Signaling in Cancer. Clin. Cancer Res. 2015, 21, 2684-2694. [CrossRef] [PubMed]

57. Singh, D.; Chan, J.M.; Zoppoli, P.; Niola, F.; Sullivan, R.; Castano, A.; Liu, E.M.; Reichel, J.; Porrati, P.; Pellegatta, S.; et al. Transforming Fusions of FGFR and TACC Genes in Human Glioblastoma. Science 2012, 337, 1231-1235. [CrossRef]

58. Di Stefano, A.L.; Picca, A.; Saragoussi, E.; Bielle, F.; Ducray, F.; Villa, C.; Eoli, M.; Paterra, R.; Bellu, L.; Mathon, B.; et al. Clinical, Molecular, and Radiomic Profile of Gliomas with FGFR3-TACC3 Fusions. Neuro-Oncology 2020, 22, 1614-1624. [CrossRef]

59. Picca, A.; Berzero, G.; Bielle, F.; Touat, M.; Savatovsky, J.; Polivka, M.; Trisolini, E.; Meunier, S.; Schmitt, Y.; Idbaih, A.; et al. FGFR1 Actionable Mutations, Molecular Specificities, and Outcome of Adult Midline Gliomas. Neurology 2018, 90, e2086-e2094. [CrossRef]

60. Di Stefano, A.L.; Fucci, A.; Frattini, V.; Labussiere, M.; Mokhtari, K.; Zoppoli, P.; Marie, Y.; Bruno, A.; Boisselier, B.; Giry, M.; et al. Detection, Characterization, and Inhibition of FGFR-TACC Fusions in IDH Wild-Type Glioma. Clin. Cancer Res. 2015, 21, 3307-3317. [CrossRef]

61. Rand, V.; Huang, J.; Stockwell, T.; Ferriera, S.; Buzko, O.; Levy, S.; Busam, D.; Li, K.; Edwards, J.B.; Eberhart, C.; et al. Sequence Survey of Receptor Tyrosine Kinases Reveals Mutations in Glioblastomas. Proc. Natl. Acad. Sci. USA 2005, 102, 14344-14349. [CrossRef]

62. Zhang, L.; Chen, L.H.; Wan, H.; Yang, R.; Wang, Z.; Feng, J.; Yang, S.; Jones, S.; Wang, S.; Zhou, W.; et al. Exome Sequencing Identifies Somatic Gain-of-Function PPM1D Mutations in Brainstem Gliomas. Nat. Genet. 2014, 46, 726-730. [CrossRef]

63. Taiho Oncology, Inc. Phase 1/2 Study of TAS-120 in Patients with Advanced Solid Tumors Harboring FGF/FGFR Aberrations. 2020. Available online: clinicaltrials.gov (accessed on 29 December 2021). 
64. Cocco, E.; Scaltriti, M.; Drilon, A. NTRK Fusion-Positive Cancers and TRK Inhibitor Therapy. Nat. Rev. Clin. Oncol. 2018, 15, 731-747. [CrossRef] [PubMed]

65. Drilon, A. TRK Inhibitors in TRK Fusion-Positive Cancers. Ann. Oncol. 2019, 30, viii23-viii30. [CrossRef] [PubMed]

66. Gambella, A.; Senetta, R.; Collemi, G.; Vallero, S.G.; Monticelli, M.; Cofano, F.; Zeppa, P.; Garbossa, D.; Pellerino, A.; Rudà, R.; et al . NTRK Fusions in Central Nervous System Tumors: A Rare, but Worthy Target. Int. J. Mol. Sci. 2020, 21, 753. [CrossRef] [PubMed]

67. Alvarez-Breckenridge, C.; Miller, J.J.; Nayyar, N.; Gill, C.M.; Kaneb, A.; D’Andrea, M.; Le, L.P.; Lee, J.; Cheng, J.; Zheng, Z.; et al. Clinical and Radiographic Response Following Targeting of BCAN-NTRK1 Fusion in Glioneuronal Tumor. NPJ Precis. Oncol. 2017, 1, 5. [CrossRef] [PubMed]

68. Hemming, M.L.; Nathenson, M.J.; Lin, J.-R.; Mei, S.; Du, Z.; Malik, K.; Marino-Enriquez, A.; Jagannathan, J.P.; Sorger, P.K.; Bertagnolli, M.; et al. Response and Mechanisms of Resistance to Larotrectinib and Selitrectinib in Metastatic Undifferentiated Sarcoma Harboring Oncogenic Fusion of NTRK1. J. Clin. Oncol. Precis. Oncol. 2020, 4, 79-90. [CrossRef] [PubMed]

69. Cocco, E.; Schram, A.M.; Kulick, A.; Misale, S.; Won, H.H.; Yaeger, R.; Razavi, P.; Ptashkin, R.; Hechtman, J.F.; Toska, E.; et al. Resistance to TRK Inhibition Mediated by Convergent MAPK Pathway Activation. Nat. Med. 2019, 25, 1422-1427. [CrossRef] [PubMed]

70. Halatsch, M.-E.; Gehrke, E.E.; Vougioukas, V.I.; Bötefür, I.C.; A-Borhani, F.; Efferth, T.; Gebhart, E.; Domhof, S.; Schmidt, U.; Buchfelder, M. Inverse Correlation of Epidermal Growth Factor Receptor Messenger RNA Induction and Suppression of Anchorage-Independent Growth by OSI-774, an Epidermal Growth Factor Receptor Tyrosine Kinase Inhibitor, in Glioblastoma Multiforme Cell Lines. J. Neurosurg. 2004, 100, 523-533. [CrossRef]

71. Rich, J.N.; Reardon, D.A.; Peery, T.; Dowell, J.M.; Quinn, J.A.; Penne, K.L.; Wikstrand, C.J.; Van Duyn, L.B.; Dancey, J.E.; McLendon, R.E.; et al. Phase II Trial of Gefitinib in Recurrent Glioblastoma. J. Clin. Oncol. 2004, 22, 133-142. [CrossRef]

72. Franceschi, E.; Cavallo, G.; Lonardi, S.; Magrini, E.; Tosoni, A.; Grosso, D.; Scopece, L.; Blatt, V.; Urbini, B.; Pession, A.; et al. Gefitinib in Patients with Progressive High-Grade Gliomas: A Multicentre Phase II Study by Gruppo Italiano Cooperativo Di Neuro-Oncologia (GICNO). Br. J. Cancer 2007, 96, 1047-1051. [CrossRef]

73. Raizer, J.J.; Abrey, L.E.; Lassman, A.B.; Chang, S.M.; Lamborn, K.R.; Kuhn, J.G.; Yung, W.K.; Gilbert, M.R.; Aldape, K.A.; Wen, P.Y.; et al. A Phase II Trial of Erlotinib in Patients with Recurrent Malignant Gliomas and Nonprogressive Glioblastoma Multiforme Postradiation Therapy. Neuro-Oncology 2010, 12, 95-103. [CrossRef]

74. Van den Bent, M.J.; Brandes, A.A.; Rampling, R.; Kouwenhoven, M.C.; Kros, J.M.; Carpentier, A.F.; Clement, P.M.; Frenay, M.; Campone, M.; Baurain, J.F.; et al. Randomized Phase II Trial of Erlotinib versus Temozolomide or Carmustine in Recurrent Glioblastoma: EORTC Brain Tumor Group Study 26034. J. Clin. Oncol. 2009, 27, 1268-1274. [CrossRef] [PubMed]

75. Yung, W.K.A.; Vredenburgh, J.J.; Cloughesy, T.F.; Nghiemphu, P.; Klencke, B.; Gilbert, M.R.; Reardon, D.A.; Prados, M.D. Safety and Efficacy of Erlotinib in First-Relapse Glioblastoma: A Phase II Open-Label Study. Neuro-Oncology 2010, 12, 1061-1070. [CrossRef] [PubMed]

76. Eisenstat, D.D.; Nabors, L.B.; Mason, W.P.; Perry, J.R.; Shapiro, W.R.; Kavan, P.; Phuphanich, S.; Fu, Y.; Cong, X.J.; Shahidi, M.; et al. A Phase II Study of Daily Afatinib (BIBW 2992) with or without Temozolomide (21/28 Days) in the Treatment of Patients with Recurrent Glioblastoma. J. Clin. Oncol. 2011, 29, 2010. [CrossRef]

77. Sepúlveda-Sánchez, J.M.; Vaz, M.Á.; Balañá, C.; Gil-Gil, M.; Reynés, G.; Gallego, Ó.; Martínez-García, M.; Vicente, E.; Quindós, M.; Luque, R.; et al. Phase II Trial of Dacomitinib, a Pan-Human EGFR Tyrosine Kinase Inhibitor, in Recurrent Glioblastoma Patients with EGFR Amplification. Neuro-Oncology 2017, 19, 1522-1531. [CrossRef] [PubMed]

78. Batchelor, T.T.; Mulholland, P.; Neyns, B.; Nabors, L.B.; Campone, M.; Wick, A.; Mason, W.; Mikkelsen, T.; Phuphanich, S.; Ashby, L.S.; et al. Phase III Randomized Trial Comparing the Efficacy of Cediranib as Monotherapy, and in Combination with Lomustine, versus Lomustine Alone in Patients with Recurrent Glioblastoma. J. Clin. Oncol. 2013, 31, 3212-3218. [CrossRef] [PubMed]

79. Galanis, E.; Anderson, S.K.; Lafky, J.M.; Uhm, J.H.; Giannini, C.; Kumar, S.K.; Kimlinger, T.K.; Northfelt, D.W.; Flynn, P.J.; Jaeckle, K.A.; et al. Phase II Study of Bevacizumab in Combination with Sorafenib in Recurrent Glioblastoma (N0776): A North Central Cancer Treatment Group Trial. Clin. Cancer Res. 2013, 19, 4816-4823. [CrossRef] [PubMed]

80. Lee, E.Q.; Kuhn, J.; Lamborn, K.R.; Abrey, L.; DeAngelis, L.M.; Lieberman, F.; Robins, H.I.; Chang, S.M.; Yung, W.K.; Drappatz, J.; et al. Phase I/II Study of Sorafenib in Combination with Temsirolimus for Recurrent Glioblastoma or Gliosarcoma: North American Brain Tumor Consortium Study 05-02. Neuro-Oncology 2012, 14, 1511-1518. [CrossRef]

81. Kreisl, T.N.; Smith, P.; Sul, J.; Salgado, C.; Iwamoto, F.M.; Shih, J.H.; Fine, H.A. Continuous Daily Sunitinib for Recurrent Glioblastoma. J. Neurooncol. 2013, 111, 41-48. [CrossRef]

82. Iwamoto, F.M.; Lamborn, K.R.; Robins, H.I.; Mehta, M.P.; Chang, S.M.; Butowski, N.A.; Deangelis, L.M.; Abrey, L.E.; Zhang, W.T.; Prados, M.D.; et al. Phase II Trial of Pazopanib (GW786034), an Oral Multi-Targeted Angiogenesis Inhibitor, for Adults with Recurrent Glioblastoma (North American Brain Tumor Consortium Study 06-02). Neuro-Oncology 2010, 12, 855-861. [CrossRef]

83. Cloughesy, T.F.; Drappatz, J.; de Groot, J.; Prados, M.D.; Reardon, D.A.; Schiff, D.; Chamberlain, M.; Mikkelsen, T.; Desjardins, A.; Ping, J.; et al. Phase II Study of Cabozantinib in Patients with Progressive Glioblastoma: Subset Analysis of Patients with Prior Antiangiogenic Therapy. Neuro-Oncology 2018, 20, 259-267. [CrossRef]

84. Alexandru, O.; Horescu, C.; Sevastre, A.-S.; Cioc, C.E.; Baloi, C.; Oprita, A.; Dricu, A. Receptor Tyrosine Kinase Targeting in Glioblastoma: Performance, Limitations and Future Approaches. Contemp. Oncol. 2020, 24, 55-66. [CrossRef] [PubMed]

85. Paulsson, J.; Ehnman, M.; Östman, A. PDGF Receptors in Tumor Biology: Prognostic and Predictive Potential. Future Oncol. 2014, 10, 1695-1708. [CrossRef] [PubMed] 
86. Raymond, E.; Brandes, A.A.; Dittrich, C.; Fumoleau, P.; Coudert, B.; Clement, P.M.; Frenay, M.; Rampling, R.; Stupp, R.; Kros, J.M.; et al. Phase II Study of Imatinib in Patients with Recurrent Gliomas of Various Histologies: A European Organisation for Research and Treatment of Cancer Brain Tumor Group Study. J. Clin. Oncol. 2008, 26, 4659-4665. [CrossRef]

87. Reardon, D.A.; Dresemann, G.; Taillibert, S.; Campone, M.; van den Bent, M.; Clement, P.; Blomquist, E.; Gordower, L.; Schultz, H.; Raizer, J.; et al. Multicentre Phase II Studies Evaluating Imatinib plus Hydroxyurea in Patients with Progressive Glioblastoma. Br. J. Cancer 2009, 101, 1995-2004. [CrossRef]

88. Odia, Y.; Sul, J.; Shih, J.H.; Kreisl, T.N.; Butman, J.A.; Iwamoto, F.M.; Fine, H.A. A Phase II Trial of Tandutinib (MLN 518) in Combination with Bevacizumab for Patients with Recurrent Glioblastoma. CNS Oncol. 2016, 5, 59-67. [CrossRef] [PubMed]

89. AbbVie A Randomized, Placebo Controlled Phase 3 Study of ABT-414 With Concurrent Chemoradiation and Adjuvant Temozolomide in Subjects with Newly Diagnosed Glioblastoma (GBM) with Epidermal Growth Factor Receptor (EGFR) Amplification (Intellance1). 2020. Available online: clinicaltrials.gov (accessed on 29 December 2021).

90. Weller, M.; Butowski, N.; Tran, D.D.; Recht, L.D.; Lim, M.; Hirte, H.; Ashby, L.; Mechtler, L.; Goldlust, S.A.; Iwamoto, F.; et al. Rindopepimut with Temozolomide for Patients with Newly Diagnosed, EGFRvIII-Expressing Glioblastoma (ACT IV): A Randomised, Double-Blind, International Phase 3 Trial. Lancet Oncol. 2017, 18, 1373-1385. [CrossRef]

91. Van den Bent, M.J.; Gao, Y.; Kerkhof, M.; Kros, J.M.; Gorlia, T.; van Zwieten, K.; Prince, J.; van Duinen, S.; Sillevis Smitt, P.A.; Taphoorn, M.; et al. Changes in the EGFR Amplification and EGFRvIII Expression between Paired Primary and Recurrent Glioblastomas. Neuro-Oncology 2015, 17, 935-941. [CrossRef]

92. Watanabe, T.; Nobusawa, S.; Kleihues, P.; Ohgaki, H. IDH1 Mutations Are Early Events in the Development of Astrocytomas and Oligodendrogliomas. Am. J. Pathol. 2009, 174, 1149-1153. [CrossRef]

93. Barthel, F.P.; Wesseling, P.; Verhaak, R.G.W. Reconstructing the Molecular Life History of Gliomas. Acta Neuropathol. 2018, 135, 649-670. [CrossRef]

94. Picca, A.; Berzero, G.; Di Stefano, A.L.; Sanson, M. The Clinical Use of IDH1 and IDH2 Mutations in Gliomas. Expert Rev. Mol. Diagn. 2018, 18, 1041-1051. [CrossRef]

95. Pirozzi, C.J.; Yan, H. The Implications of IDH Mutations for Cancer Development and Therapy. Nat. Rev. Clin. Oncol. 2021, 18, 645-661. [CrossRef] [PubMed]

96. Dang, L.; White, D.W.; Gross, S.; Bennett, B.D.; Bittinger, M.A.; Driggers, E.M.; Fantin, V.R.; Jang, H.G.; Jin, S.; Keenan, M.C.; et al Cancer-Associated IDH1 Mutations Produce 2-Hydroxyglutarate. Nature 2009, 462, 739-744. [CrossRef] [PubMed]

97. Xu, W.; Yang, H.; Liu, Y.; Yang, Y.; Wang, P.; Kim, S.-H.; Ito, S.; Yang, C.; Wang, P.; Xiao, M.-T.; et al. Oncometabolite 2Hydroxyglutarate Is a Competitive Inhibitor of $\alpha$-Ketoglutarate-Dependent Dioxygenases. Cancer Cell 2011, 19, 17-30. [CrossRef] [PubMed]

98. Turcan, S.; Rohle, D.; Goenka, A.; Walsh, L.A.; Fang, F.; Yilmaz, E.; Campos, C.; Fabius, A.W.M.; Lu, C.; Ward, P.S.; et al. IDH1 Mutation Is Sufficient to Establish the Glioma Hypermethylator Phenotype. Nature 2012, 483, 479-483. [CrossRef] [PubMed]

99. Johannessen, T.-C.A.; Mukherjee, J.; Viswanath, P.; Ohba, S.; Ronen, S.M.; Bjerkvig, R.; Pieper, R.O. Rapid Conversion of Mutant IDH1 from Driver to Passenger in a Model of Human Gliomagenesis. Mol. Cancer Res. 2016, 14, 976-983. [CrossRef]

100. Mazor, T.; Chesnelong, C.; Pankov, A.; Jalbert, L.E.; Hong, C.; Hayes, J.; Smirnov, I.V.; Marshall, R.; Souza, C.F.; Shen, Y.; et al. Clonal Expansion and Epigenetic Reprogramming Following Deletion or Amplification of Mutant IDH1. Proc. Natl. Acad. Sci. USA 2017, 114, 10743-10748. [CrossRef]

101. Verhaak, R.G.W.; Hoadley, K.A.; Purdom, E.; Wang, V.; Qi, Y.; Wilkerson, M.D.; Miller, C.R.; Ding, L.; Golub, T.; Mesirov, J.P.; et al. Integrated Genomic Analysis Identifies Clinically Relevant Subtypes of Glioblastoma Characterized by Abnormalities in PDGFRA, IDH1, EGFR, and NF1. Cancer Cell 2010, 17, 98-110. [CrossRef]

102. Amankulor, N.M.; Kim, Y.; Arora, S.; Kargl, J.; Szulzewsky, F.; Hanke, M.; Margineantu, D.H.; Rao, A.; Bolouri, H.; Delrow, J.; et al. Mutant IDH1 Regulates the Tumor-Associated Immune System in Gliomas. Genes Dev. 2017, 31, 774-786. [CrossRef]

103. Zhang, X.; Rao, A.; Sette, P.; Deibert, C.; Pomerantz, A.; Kim, W.J.; Kohanbash, G.; Chang, Y.; Park, Y.; Engh, J.; et al. IDH Mutant Gliomas Escape Natural Killer Cell Immune Surveillance by Downregulation of NKG2D Ligand Expression. Neuro-Oncology 2016, 18, 1402-1412. [CrossRef]

104. Bunse, L.; Pusch, S.; Bunse, T.; Sahm, F.; Sanghvi, K.; Friedrich, M.; Alansary, D.; Sonner, J.K.; Green, E.; Deumelandt, K.; et al. Suppression of Antitumor T Cell Immunity by the Oncometabolite (R)-2-Hydroxyglutarate. Nat. Med. 2018, 24, $1192-1203$. [CrossRef]

105. Sampson, J.H.; Gunn, M.D.; Fecci, P.E.; Ashley, D.M. Brain Immunology and Immunotherapy in Brain Tumours. Nat. Rev. Cancer 2020, 20, 12-25. [CrossRef] [PubMed]

106. Fanelli, G.N.; Grassini, D.; Ortenzi, V.; Pasqualetti, F.; Montemurro, N.; Perrini, P.; Naccarato, A.G.; Scatena, C. Decipher the Glioblastoma Microenvironment: The First Milestone for New Groundbreaking Therapeutic Strategies. Genes 2021, $12,445$. [CrossRef] [PubMed]

107. Lim, M.; Xia, Y.; Bettegowda, C.; Weller, M. Current State of Immunotherapy for Glioblastoma. Nat. Rev. Clin. Oncol. 2018, 15, 422-442. [CrossRef] [PubMed]

108. Reardon, D.A.; Brandes, A.A.; Omuro, A.; Mulholland, P.; Lim, M.; Wick, A.; Baehring, J.; Ahluwalia, M.S.; Roth, P.; Bähr, O.; et al. Effect of Nivolumab vs Bevacizumab in Patients with Recurrent Glioblastoma: The CheckMate 143 Phase 3 Randomized Clinical Trial. JAMA Oncol. 2020, 6, 1003-1010. [CrossRef] 
109. Medikonda, R.; Dunn, G.; Rahman, M.; Fecci, P.; Lim, M. A Review of Glioblastoma Immunotherapy. J. Neurooncol. 2021, 151, 41-53. [CrossRef]

110. Grossman, S.A.; Ye, X.; Lesser, G.; Sloan, A.; Carraway, H.; Desideri, S.; Piantadosi, S.; NABTT CNS Consortium. Immunosuppression in Patients with High-Grade Gliomas Treated with Radiation and Temozolomide. Clin. Cancer Res. 2011, 17, 5473-5480. [CrossRef]

111. Hughes, M.A.; Parisi, M.; Grossman, S.; Kleinberg, L. Primary Brain Tumors Treated with Steroids and Radiotherapy: Low CD4 Counts and Risk of Infection. Int. J. Radiat. Oncol. Biol. Phys. 2005, 62, 1423-1426. [CrossRef]

112. Chongsathidkiet, P.; Jackson, C.; Koyama, S.; Loebel, F.; Cui, X.; Farber, S.H.; Woroniecka, K.; Elsamadicy, A.A.; Dechant, C.A.; Kemeny, H.R.; et al. Sequestration of T Cells in Bone Marrow in the Setting of Glioblastoma and Other Intracranial Tumors. Nat. Med. 2018, 24, 1459-1468. [CrossRef]

113. Tawbi, H.A.; Forsyth, P.A.; Algazi, A.; Hamid, O.; Hodi, F.S.; Moschos, S.J.; Khushalani, N.I.; Lewis, K.; Lao, C.D.; Postow, M.A.; et al. Combined Nivolumab and Ipilimumab in Melanoma Metastatic to the Brain. N. Engl. J. Med. 2018, 379, 722-730. [CrossRef]

114. Zhai, L.; Bell, A.; Ladomersky, E.; Lauing, K.L.; Bollu, L.; Sosman, J.A.; Zhang, B.; Wu, J.D.; Miller, S.D.; Meeks, J.J.; et al. Immunosuppressive IDO in Cancer: Mechanisms of Action, Animal Models, and Targeting Strategies. Front. Immunol. 2020, 11, 1185. [CrossRef]

115. Cloughesy, T.F.; Mochizuki, A.Y.; Orpilla, J.R.; Hugo, W.; Lee, A.H.; Davidson, T.B.; Wang, A.C.; Ellingson, B.M.; Rytlewski, J.A.; Sanders, C.M.; et al. Neoadjuvant Anti-PD-1 Immunotherapy Promotes a Survival Benefit with Intratumoral and Systemic Immune Responses in Recurrent Glioblastoma. Nat. Med. 2019, 25, 477-486. [CrossRef] [PubMed]

116. Alexandrov, L.B.; Nik-Zainal, S.; Wedge, D.C.; Aparicio, S.A.J.R.; Behjati, S.; Biankin, A.V.; Bignell, G.R.; Bolli, N.; Borg, A.; Børresen-Dale, A.-L.; et al. Signatures of Mutational Processes in Human Cancer. Nature 2013, 500, 415-421. [CrossRef]

117. Le, D.T.; Uram, J.N.; Wang, H.; Bartlett, B.R.; Kemberling, H.; Eyring, A.D.; Skora, A.D.; Luber, B.S.; Azad, N.S.; Laheru, D.; et al. PD-1 Blockade in Tumors with Mismatch-Repair Deficiency. N. Engl. J. Med. 2015, 372, 2509-2520. [CrossRef] [PubMed]

118. Marabelle, A.; Le, D.T.; Ascierto, P.A.; Di Giacomo, A.M.; De Jesus-Acosta, A.; Delord, J.-P.; Geva, R.; Gottfried, M.; Penel, N.; Hansen, A.R.; et al. Efficacy of Pembrolizumab in Patients with Noncolorectal High Microsatellite Instability/Mismatch Repair-Deficient Cancer: Results from the Phase II KEYNOTE-158 Study. J. Clin. Oncol. 2020, 38, 1-10. [CrossRef] [PubMed]

119. Touat, M.; Li, Y.Y.; Boynton, A.N.; Spurr, L.F.; Iorgulescu, J.B.; Bohrson, C.L.; Cortes-Ciriano, I.; Birzu, C.; Geduldig, J.E.; Pelton, K.; et al. Mechanisms and Therapeutic Implications of Hypermutation in Gliomas. Nature 2020, 580, 517-523. [CrossRef] [PubMed]

120. Prost, D.; Bielle, F.; Ligon, K.L.; Touat, M. Mutational Burden and Immune Recognition of Gliomas. Curr. Opin. Oncol. 2021, 33, 626-634. [CrossRef]

121. Indraccolo, S.; Lombardi, G.; Fassan, M.; Pasqualini, L.; Giunco, S.; Marcato, R.; Gasparini, A.; Candiotto, C.; Nalio, S.; Fiduccia, P.; et al. Genetic, Epigenetic, and Immunologic Profiling of MMR-Deficient Relapsed Glioblastoma. Clin. Cancer Res. 2019, 25, 1828-1837. [CrossRef]

122. McGrail, D.J.; Pilié, P.G.; Rashid, N.U.; Voorwerk, L.; Slagter, M.; Kok, M.; Jonasch, E.; Khasraw, M.; Heimberger, A.B.; Lim, B.; et al. High Tumor Mutation Burden Fails to Predict Immune Checkpoint Blockade Response across All Cancer Types. Ann. Oncol. 2021, 32, 661-672. [CrossRef]

123. Lombardi, G.; Barresi, V.; Indraccolo, S.; Simbolo, M.; Fassan, M.; Mandruzzato, S.; Simonelli, M.; Caccese, M.; Pizzi, M.; Fassina, A.; et al. Pembrolizumab Activity in Recurrent High-Grade Gliomas with Partial or Complete Loss of Mismatch Repair Protein Expression: A Monocentric, Observational and Prospective Pilot Study. Cancers 2020, 12, 2283. [CrossRef]

124. Bouffet, E.; Larouche, V.; Campbell, B.B.; Merico, D.; de Borja, R.; Aronson, M.; Durno, C.; Krueger, J.; Cabric, V.; Ramaswamy, V.; et al. Immune Checkpoint Inhibition for Hypermutant Glioblastoma Multiforme Resulting from Germline Biallelic Mismatch Repair Deficiency. J. Clin. Oncol. 2016, 34, 2206-2211. [CrossRef]

125. June, C.H.; Sadelain, M. Chimeric Antigen Receptor Therapy. N. Engl. J. Med. 2018, 379, 64-73. [CrossRef] [PubMed]

126. Karschnia, P.; Teske, N.; Thon, N.; Subklewe, M.; Tonn, J.-C.; Dietrich, J.; von Baumgarten, L. Chimeric Antigen Receptor T Cells for Glioblastoma: Current Concepts, Challenges, and Future Perspectives. Neurology 2021, 97, 218-230. [CrossRef] [PubMed]

127. Soler, D.C.; Kerstetter-Fogle, A.; McCormick, T.S.; Sloan, A.E. Using Chimeric Antigen Receptor T-Cell Therapy to Fight Glioblastoma Multiforme: Past, Present and Future Developments. J. Neurooncol. 2022, 156, 81-96. [CrossRef] [PubMed]

128. Brown, C.E.; Alizadeh, D.; Starr, R.; Weng, L.; Wagner, J.R.; Naranjo, A.; Ostberg, J.R.; Blanchard, M.S.; Kilpatrick, J.; Simpson, J.; et al. Regression of Glioblastoma after Chimeric Antigen Receptor T-Cell Therapy. N. Engl. J. Med. 2016, 375, $2561-2569$. [CrossRef] [PubMed]

129. Brown, C.E.; Badie, B.; Barish, M.E.; Weng, L.; Ostberg, J.R.; Chang, W.-C.; Naranjo, A.; Starr, R.; Wagner, J.; Wright, C.; et al. Bioactivity and Safety of IL13R $\alpha 2$-Redirected Chimeric Antigen Receptor CD8+ T Cells in Patients with Recurrent Glioblastoma. Clin. Cancer Res. 2015, 21, 4062-4072. [CrossRef]

130. O’Rourke, D.M.; Nasrallah, M.P.; Desai, A.; Melenhorst, J.J.; Mansfield, K.; Morrissette, J.J.D.; Martinez-Lage, M.; Brem, S.; Maloney, E.; Shen, A.; et al. A Single Dose of Peripherally Infused EGFRvIII-Directed CAR T Cells Mediates Antigen Loss and Induces Adaptive Resistance in Patients with Recurrent Glioblastoma. Sci. Transl. Med. 2017, 9, 399. [CrossRef]

131. Goff, S.L.; Morgan, R.A.; Yang, J.C.; Sherry, R.M.; Robbins, P.F.; Restifo, N.P.; Feldman, S.A.; Lu, Y.-C.; Lu, L.; Zheng, Z.; et al. Pilot Trial of Adoptive Transfer of Chimeric Antigen Receptor-Transduced T Cells Targeting EGFRvIII in Patients with Glioblastoma. J. Immunother. 2019, 42, 126-135. [CrossRef] 
132. Ahmed, N.; Brawley, V.; Hegde, M.; Bielamowicz, K.; Kalra, M.; Landi, D.; Robertson, C.; Gray, T.L.; Diouf, O.; Wakefield, A.; et al. HER2-Specific Chimeric Antigen Receptor-Modified Virus-Specific T Cells for Progressive Glioblastoma: A Phase 1 Dose-Escalation Trial. JAMA Oncol. 2017, 3, 1094-1101. [CrossRef]

133. Brudno, J.N.; Kochenderfer, J.N. Recent Advances in CAR T-Cell Toxicity: Mechanisms, Manifestations and Management. Blood Rev. 2019, 34, 45-55. [CrossRef]

134. Berzero, B.; Picca, A.; Psimaras, D. Neurological Complications of Chimeric Antigen Receptor T Cells and Immune-Checkpoint Inhibitors: Ongoing Challenges in Daily Practice. Available online: https:/ / pubmed.ncbi.nlm.nih.gov/32852312/ (accessed on 14 October 2020).

135. Wang, D.; Starr, R.; Chang, W.-C.; Aguilar, B.; Alizadeh, D.; Wright, S.L.; Yang, X.; Brito, A.; Sarkissian, A.; Ostberg, J.R.; et al. Chlorotoxin-Directed CAR T Cells for Specific and Effective Targeting of Glioblastoma. Sci. Transl. Med. 2020, 12, eaaw2672. [CrossRef]

136. Bielamowicz, K.; Fousek, K.; Byrd, T.T.; Samaha, H.; Mukherjee, M.; Aware, N.; Wu, M.-F.; Orange, J.S.; Sumazin, P.; Man, T.-K.; et al. Trivalent CAR T Cells Overcome Interpatient Antigenic Variability in Glioblastoma. Neuro-Oncology 2018, 20, 506-518. [CrossRef] [PubMed]

137. Choe, J.H.; Watchmaker, P.B.; Simic, M.S.; Gilbert, R.D.; Li, A.W.; Krasnow, N.A.; Downey, K.M.; Yu, W.; Carrera, D.A.; Celli, A.; et al. SynNotch-CAR T Cells Overcome Challenges of Specificity, Heterogeneity, and Persistence in Treating Glioblastoma. Sci. Transl. Med. 2021, 13, 591. [CrossRef] [PubMed]

138. Banerjee, K.; Núñez, F.J.; Haase, S.; McClellan, B.L.; Faisal, S.M.; Carney, S.V.; Yu, J.; Alghamri, M.S.; Asad, A.S.; Candia, A.J.N.; et al. Current Approaches for Glioma Gene Therapy and Virotherapy. Front. Mol. Neurosci. 2021, 14, 621831. [CrossRef] [PubMed]

139. Zhang, D.Y.; Singer, L.; Sonabend, A.M.; Lukas, R.V. Gene Therapy for the Treatment of Malignant Glioma. Adv. Oncol. 2021, 1, 189-202. [CrossRef]

140. Wang, J.L.; Scheitler, K.M.; Wenger, N.M.; Elder, J.B. Viral Therapies for Glioblastoma and High-Grade Gliomas in Adults: A Systematic Review. Neurosurg. Focus 2021, 50, E2. [CrossRef]

141. Rainov, N.G. A Phase III Clinical Evaluation of Herpes Simplex Virus Type 1 Thymidine Kinase and Ganciclovir Gene Therapy as an Adjuvant to Surgical Resection and Radiation in Adults with Previously Untreated Glioblastoma Multiforme. Hum. Gene Ther. 2000, 11, 2389-2401. [CrossRef]

142. Westphal, M.; Ylä-Herttuala, S.; Martin, J.; Warnke, P.; Menei, P.; Eckland, D.; Kinley, J.; Kay, R.; Ram, Z.; ASPECT Study Group. Adenovirus-Mediated Gene Therapy with Sitimagene Ceradenovec Followed by Intravenous Ganciclovir for Patients with Operable High-Grade Glioma (ASPECT): A Randomised, Open-Label, Phase 3 Trial. Lancet Oncol. 2013, 14, 823-833. [CrossRef]

143. Wheeler, L.A.; Manzanera, A.G.; Bell, S.D.; Cavaliere, R.; McGregor, J.M.; Grecula, J.C.; Newton, H.B.; Lo, S.S.; Badie, B.; Portnow, J.; et al. Phase II Multicenter Study of Gene-Mediated Cytotoxic Immunotherapy as Adjuvant to Surgical Resection for Newly Diagnosed Malignant Glioma. Neuro-Oncology 2016, 18, 1137-1145. [CrossRef]

144. Ji, N.; Weng, D.; Liu, C.; Gu, Z.; Chen, S.; Guo, Y.; Fan, Z.; Wang, X.; Chen, J.; Zhao, Y.; et al. Adenovirus-Mediated Delivery of Herpes Simplex Virus Thymidine Kinase Administration Improves Outcome of Recurrent High-Grade Glioma. Oncotarget 2016, 7, 4369-4378. [CrossRef]

145. Mitchell, L.A.; Lopez Espinoza, F.; Mendoza, D.; Kato, Y.; Inagaki, A.; Hiraoka, K.; Kasahara, N.; Gruber, H.E.; Jolly, D.J.; Robbins, J.M. Toca 511 Gene Transfer and Treatment with the Prodrug, 5-Fluorocytosine, Promotes Durable Antitumor Immunity in a Mouse Glioma Model. Neuro-Oncology 2017, 19, 930-939. [CrossRef]

146. Cloughesy, T.F.; Landolfi, J.; Vogelbaum, M.A.; Ostertag, D.; Elder, J.B.; Bloomfield, S.; Carter, B.; Chen, C.C.; Kalkanis, S.N.; Kesari, S.; et al. Durable Complete Responses in Some Recurrent High-Grade Glioma Patients Treated with Toca $511+$ Toca FC. Neuro-Oncology 2018, 20, 1383-1392. [CrossRef] [PubMed]

147. Cloughesy, T.F.; Petrecca, K.; Walbert, T.; Butowski, N.; Salacz, M.; Perry, J.; Damek, D.; Bota, D.; Bettegowda, C.; Zhu, J.-J.; et al. Effect of Vocimagene Amiretrorepvec in Combination with Flucytosine vs Standard of Care on Survival Following Tumor Resection in Patients with Recurrent High-Grade Glioma: A Randomized Clinical Trial. JAMA Oncol. 2020, 6, 1939-1946. [CrossRef] [PubMed]

148. Chiocca, E.A.; Yu, J.S.; Lukas, R.V.; Solomon, I.H.; Ligon, K.L.; Nakashima, H.; Triggs, D.A.; Reardon, D.A.; Wen, P.; Stopa, B.M.; et al. Regulatable Interleukin-12 Gene Therapy in Patients with Recurrent High-Grade Glioma: Results of a Phase 1 Trial. Sci. Transl. Med. 2019, 11, eaaw5680. [CrossRef] [PubMed]

149. Chiocca, E.A.; Gelb, A.B.; Chen, C.C.; Rao, G.; Reardon, D.A.; Wen, P.Y.; Bi, W.L.; Peruzzi, P.; Amidei, C.; Triggs, D.; et al. Combined Immunotherapy with Controlled Interleukin-12 Gene Therapy and Immune Checkpoint Blockade in Recurrent Glioblastoma: An Open-Label, Multi-Institutional Phase 1 Trial. Neuro-Oncology 2021, noab271. [CrossRef] [PubMed]

150. Brenner, A.J.; Peters, K.B.; Vredenburgh, J.; Bokstein, F.; Blumenthal, D.T.; Yust-Katz, S.; Peretz, I.; Oberman, B.; Freedman, L.S.; Ellingson, B.M.; et al. Safety and Efficacy of VB-111, an Anticancer Gene Therapy, in Patients with Recurrent Glioblastoma: Results of a Phase I/II Study. Neuro-Oncology 2020, 22, 694-704. [CrossRef] [PubMed]

151. Cloughesy, T.F.; Brenner, A.; de Groot, J.F.; Butowski, N.A.; Zach, L.; Campian, J.L.; Ellingson, B.M.; Freedman, L.S.; Cohen, Y.C.; Lowenton-Spier, N.; et al. A Randomized Controlled Phase III Study of VB-111 Combined with Bevacizumab vs Bevacizumab Monotherapy in Patients with Recurrent Glioblastoma (GLOBE). Neuro-Oncology 2020, 22, 705-717. [CrossRef]

152. Martuza, R.L.; Malick, A.; Markert, J.M.; Ruffner, K.L.; Coen, D.M. Experimental Therapy of Human Glioma by Means of a Genetically Engineered Virus Mutant. Science 1991, 252, 854-856. [CrossRef] 
153. Papanastassiou, V.; Rampling, R.; Fraser, M.; Petty, R.; Hadley, D.; Nicoll, J.; Harland, J.; Mabbs, R.; Brown, M. The Potential for Efficacy of the Modified (ICP 34.5(-)) Herpes Simplex Virus HSV1716 Following Intratumoural Injection into Human Malignant Glioma: A Proof of Principle Study. Gene Ther. 2002, 9, 398-406. [CrossRef]

154. Harrow, S.; Papanastassiou, V.; Harland, J.; Mabbs, R.; Petty, R.; Fraser, M.; Hadley, D.; Patterson, J.; Brown, S.M.; Rampling, R. HSV1716 Injection into the Brain Adjacent to Tumour Following Surgical Resection of High-Grade Glioma: Safety Data and Long-Term Survival. Gene Ther. 2004, 11, 1648-1658. [CrossRef]

155. Markert, J.M.; Medlock, M.D.; Rabkin, S.D.; Gillespie, G.Y.; Todo, T.; Hunter, W.D.; Palmer, C.A.; Feigenbaum, F.; Tornatore, C.; Tufaro, F; et al. Conditionally Replicating Herpes Simplex Virus Mutant, G207 for the Treatment of Malignant Glioma: Results of a Phase I Trial. Gene Ther. 2000, 7, 867-874. [CrossRef]

156. Markert, J.M.; Liechty, P.G.; Wang, W.; Gaston, S.; Braz, E.; Karrasch, M.; Nabors, L.B.; Markiewicz, M.; Lakeman, A.D.; Palmer, C.A.; et al. Phase Ib Trial of Mutant Herpes Simplex Virus G207 Inoculated Pre-and Post-Tumor Resection for Recurrent GBM. Mol. Ther. 2009, 17, 199-207. [CrossRef] [PubMed]

157. Lang, F.F.; Conrad, C.; Gomez-Manzano, C.; Yung, W.K.A.; Sawaya, R.; Weinberg, J.S.; Prabhu, S.S.; Rao, G.; Fuller, G.N.; Aldape, K.D.; et al. Phase I Study of DNX-2401 (Delta-24-RGD) Oncolytic Adenovirus: Replication and Immunotherapeutic Effects in Recurrent Malignant Glioma. J. Clin. Oncol. 2018, 36, 1419-1427. [CrossRef] [PubMed]

158. Aiken, R.; Chen, C.; Cloughesy, T.; Colman, H.; Daras, M.; Groves, M.; Khagi, S.; Kumthekar, P.; Lang, F.; Nassiri, F.; et al ATIM-33. Interim Results of a Phase II Multi-Center Study of Oncolytic Adenovirus DNX-2401 with Pembrolizumab for Recurrent Glioblastoma.; Captive Study (Keynote-192). Neuro-Oncology 2019, 21, vi8-vi9. [CrossRef]

159. Zadeh, G.; Daras, M.; Cloughesy, T.F.; Colman, H.; Kumthekar, P.U.; Chen, C.C.; Aiken, R.; Groves, M.D.; Ong, S.; Ramakrishna, R.; et al. LTBK-04. Phase 2 Multicenter Study of the Oncolytic Adenovirus DNX-2401 (Tasadenoturev) in Combination with Pembrolizumab for Recurrent Glioblastoma.; Captive Study (Keynote-192). Neuro-Oncology 2020, 22, ii237. [CrossRef]

160. Lowenstein, P.R.; Castro, M.G. Evolutionary Basis of a New Gene- and Immune-Therapeutic Approach for the Treatment of Malignant Brain Tumors: From Mice to Clinical Trials for Glioma Patients. Clin. Immunol. 2018, 189, 43-51. [CrossRef]

161. Candolfi, M.; Yagiz, K.; Foulad, D.; Alzadeh, G.E.; Tesarfreund, M.; Muhammad, A.K.M.G.; Puntel, M.; Kroeger, K.M.; Liu, C.; Lee, S.; et al. Release of HMGB1 in Response to Proapoptotic Glioma Killing Strategies: Efficacy and Neurotoxicity. Clin. Cancer Res. 2009, 15, 4401-4414. [CrossRef]

162. Curtin, J.F.; Liu, N.; Candolfi, M.; Xiong, W.; Assi, H.; Yagiz, K.; Edwards, M.R.; Michelsen, K.S.; Kroeger, K.M.; Liu, C.; et al. HMGB1 Mediates Endogenous TLR2 Activation and Brain Tumor Regression. PLoS Med. 2009, 6, e10. [CrossRef]

163. Mineharu, Y.; King, G.D.; Muhammad, A.G.; Bannykh, S.; Kroeger, K.M.; Liu, C.; Lowenstein, P.R.; Castro, M.G. Engineering the Brain Tumor Microenvironment Enhances the Efficacy of Dendritic Cell Vaccination: Implications for Clinical Trial Design. Clin. Cancer Res. 2011, 17, 4705-4718. [CrossRef]

164. Kamran, N.; Kadiyala, P.; Saxena, M.; Candolfi, M.; Li, Y.; Moreno-Ayala, M.A.; Raja, N.; Shah, D.; Lowenstein, P.R.; Castro, M.G. Immunosuppressive Myeloid Cells' Blockade in the Glioma Microenvironment Enhances the Efficacy of Immune-Stimulatory Gene Therapy. Mol. Ther. 2017, 25, 232-248. [CrossRef]

165. Lowenstein, P.R.; Orringer, D.A.; Sagher, O.; Heth, J.; Hervey-Jumper, S.L.; Mammoser, A.G.; Junck, L.; Leung, D.; Umemura, Y.; Lawrence, T.S.; et al. First-in-Human Phase I Trial of the Combination of Two Adenoviral Vectors Expressing HSV1-TK and FLT3L for the Treatment of Newly Diagnosed Resectable Malignant Glioma: Initial Results from the Therapeutic Reprogramming of the Brain Immune System. J. Clin. Oncol. 2019, 37, 2019. [CrossRef]

166. McDannold, N.; Vykhodtseva, N.; Hynynen, K. Effects of Acoustic Parameters and Ultrasound Contrast Agent Dose on FocusedUltrasound Induced Blood-Brain Barrier Disruption. Ultrasound Med. Biol. 2008, 34, 930-937. [CrossRef] [PubMed]

167. Hynynen, K.; McDannold, N.; Vykhodtseva, N.; Jolesz, F.A. Noninvasive MR Imaging-Guided Focal Opening of the Blood-Brain Barrier in Rabbits. Radiology 2001, 220, 640-646. [CrossRef]

168. Beccaria, K.; Canney, M.; Goldwirt, L.; Fernandez, C.; Piquet, J.; Perier, M.-C.; Lafon, C.; Chapelon, J.-Y.; Carpentier, A. UltrasoundInduced Opening of the Blood-Brain Barrier to Enhance Temozolomide and Irinotecan Delivery: An Experimental Study in Rabbits. J. Neurosurg. 2016, 124, 1602-1610. [CrossRef] [PubMed]

169. Carpentier, A.; Canney, M.; Vignot, A.; Reina, V.; Beccaria, K.; Horodyckid, C.; Karachi, C.; Leclercq, D.; Lafon, C.; Chapelon, J.-Y.; et al. Clinical Trial of Blood-Brain Barrier Disruption by Pulsed Ultrasound. Sci. Transl. Med. 2016, 8, 343re2. [CrossRef] [PubMed]

170. Treat, L.H.; McDannold, N.; Zhang, Y.; Vykhodtseva, N.; Hynynen, K. Improved Anti-Tumor Effect of Liposomal Doxorubicin after Targeted Blood-Brain Barrier Disruption by MRI-Guided Focused Ultrasound in Rat Glioma. Ultrasound Med. Biol. 2012, 38, 1716-1725. [CrossRef] [PubMed]

171. Horodyckid, C.; Canney, M.; Vignot, A.; Boisgard, R.; Drier, A.; Huberfeld, G.; François, C.; Prigent, A.; Santin, M.D.; Adam, C.; et al. Safe Long-Term Repeated Disruption of the Blood-Brain Barrier Using an Implantable Ultrasound Device: A Multiparametric Study in a Primate Model. J. Neurosurg. 2017, 126, 1351-1361. [CrossRef] [PubMed] 